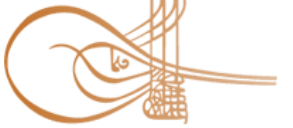

www.turkishstudies.net/education
eISSN: 2667-5609

Research Article / Araștırma Makalesi
INTERNATIONAL

BALKAN
UNIVERSITY

Sponsored by IBU

\title{
Yabancı Dil Olarak Türkçe Öğretiminde Kullanılan Ders Kitaplarındaki Şahsiyetler Üzerine Bir İnceleme*
}

\author{
An Examination On The Personality In The Books Used In Turkish Language Teaching As A \\ Foreign Language
}

\author{
Emrah Boylu** - Kübra Başkaya***
}

\begin{abstract}
The aim of the study is to determine the personalities in the textbooks used in teaching Turkish as a foreign language and to reveal how often and how these persons are handled in the course books. Document analysis technique was used in the study. In the study, "Seven Climate and Istanbul Turkish for foreigners" sets were selected as samples. As a result of the research, athletes, artists, writers, poets, poets, clergymen, statesmen, etc. in the sum of all levels of both sets. It was determined that there were 97 people in the Istanbul set and 164 people in the Seven Climate, in various categories. In A1, A2, B1 and B2 levels, in the Seven Climate books, the rate of giving and the way of giving is higher than that of Istanbul, but in the C1 and C2 levels, the rate of giving the figures of both books is very close to each other. When an evaluation is made on the way personalities are given, it is seen that $66(64,02 \%)$ of the personalities in the Istanbul book are given as names, while $67(40,85 \%)$ are given as names in the Seven Climate. When it is looked at the rate of the personalities given in the text, it is to remark that $17(16.49 \%)$ of the Istanbul book and $38(23.17 \%)$ of the seven climate have the characteristics of the personalities. When it is looked at the proportion of the personalities processed in the context of the text, it is seen that there are $20(19.4 \%)$ people in Istanbul and 59 (35.97\%) people in Seven Climate. When both studies are evaluated together, it is concluded that the relevant sets do not include personalities with a systematic approach. Based on all these results, various studies should be conducted on who should be the personalities to be included in the textbooks, and in these studies, the personalities that should be included in the textbooks should be determined consulting the opinion of the people come to the fore with their cultural identity in Turkey and the ideas of the teachers, academics etc. who teach in the field.
\end{abstract}

Structured Abstract: Introduction The first of the first two situations that stand out among the competencies of knowing a foreign language is to be able to communicate with the speakers of the target language as their mother tongue; the second is to learn the culture of those who speak that language. "Therefore, the act of

\footnotetext{
* Bu çalışma, 16-18 Ekim 2019 da Samsun'da düzenlenen XI Dünya Dili Türkçe Sempozyumunda sözlü bildiri olarak sunulmuştur.

** Dr. Öğr. Üyesi, İstanbul Aydın Üniversitesi, Eğitim Fakültesi, Türkçe Eğitimi Anabilim Dalı

Assist. Prof. Dr., Istanbul Aydin University, Faculty of Education, Department of Turkish Education

ORCID 0000-0001-9529-7369

emrahboylu@aydin.edu.tr

**** Öğretim Görevlisi, İstanbul Aydın Üniversitesi, Aydın TÖMER

Lecturer, Istanbul Aydin University, Aydin TOMER

ORCID 0000-0002-0299-9781

kubrabaskaya@aydin.edu.tr

Cite as/ Atıf: Boylu, E. \& Başkaya, K. (2020). Yabancı dil olarak Türkçe öğretiminde kullanılan ders kitaplarındaki

şahsiyetler üzerine bir inceleme. Turkish Studies - Education, 15(3), 1573-1605. https://dx.doi.org/10.29228/TurkishStudies.42648

Received/Geliş: 25 March/Mart 2020

Accepted/Kabul: 01 June/Haziran 2020

Copyright (C) INTAC LTD, Turkey

Checked by plagiarism software

Published/Yayin: 25 June/Haziran 2020

CC BY-NC 4.0
} 
communication is not basically seen as a linguistic message exchange, but rather a socially meaningful section in which social rules and functions have been previously agreed upon or use of language as far as is known plays an important role." (Asemota, 2015: 16). In this context, the culture of that society must also be known in order to establish a correct and effective communication in the target language desired to learn. For this reason, the issue of cultural transfer, especially in foreign language teaching, has been one of the main topics discussed from past to present. Because, as Spencer-Oatey (2012) points out, culture is a difficult term to define, and in 1952, American anthropologists Kroeber and Kluckhohn critically reviewed the concepts and definitions of culture and compiled a list of 164 different definitions. In this regard, Han and Zhang (2020: 449) stated that getting to know another culture is a very difficult task, and acting in another culture is more difficult, and there must be at least four goals that foreign language teachers will teach in their own language classes in the context of cultural transfer, such as adapting students to cultural differences, helping the student to transcend his own culture and see events as members of the target culture, underlining the inseparability of understanding language and culture through various target class practices, emphasizing the communication culture and ensuring that students communicate successfully with foreigners. This clearly reveals the importance of cultural transfer in language teaching.

Demir (2014: 56) clearly shows how important culture transfer is, expressing the importance of culture transfer/teaching in language teaching process with the proverb in Turkish "Human is the enemy of beings he does not know." and explaining the basic thing expected from cultural transfer as "breaking down the negative connotation of the "other" concept and getting to know the "other" better". In this connection, Koşger (2015: 411) states that in real communication situations, there are some components (including different dimensions such as economy, politics, history, traditions, humor etc., culture also includes non-verbal communication components such as gestures and facial expressions as well as various abbreviations, idioms, proverbs) formed in the culture of a society and in this sense, the culture of the target language in foreign language teaching should be transferred to students with different dimensions. This shows that culture is a complex phenomenon that contains more than one component. Moran (2001: 24), Brody (2003) and Bennett, who define culture as "the developing lifestyle of a group of people associated with a common set of products, based on a common set of perspectives of the world and within a certain social context", also added the community and people to the cultural dimensions determined by Bennett and Allen (2003) as products, practices and opinions, and advocated the full use of these components in textbooks.

The five components of the culture given above by Moran, and the contents of these components are as follows: Products (e.g. tools, food, clothes), practices (verbal and non-verbal language, actions and interactions, taboos), opinions (values, beliefs), communities (race, gender, religion, etc.), and people (individuals).

Within the scope of the above information, Peterson (2004), Chen (2004) and Lee (2009) divided culture into two: big "C" and small "c". Lee (2009: 78) has classified the art, history, geography, business world, education, festivals and traditions of society under the big " $\mathrm{C}$ " culture; on the other hand, he has classified socio-cultural values, norms, daily routines, lifestyle, dishes etc. of the society in small "c" culture. In this context, when we look at the elements under these two cultures, it is seen that personalities are generally used especially in transferring the big culture (C) to the textbooks. As stated by Güleç and Gürsoy (2015), cultural elements such as arts, literature, history, music, and sports belonging to a society are generally given over individuals who have gained a certain reputation in these areas and are identified with the society in that area. This clearly reveals that people (personalities) should be included in the textbooks as both one of the culture components and as a tool for the transfer of big culture.

\section{Aim Of The Research}

The purpose of this research is to determine which personalities are included in the textbooks used in teaching Turkish as a foreign language. The sub-aims of the research are given below.

- Which personalities are included in the "İstanbul" and "Yedi İklim" sets?

- What is the distribution of the figures given in the "İstanbul" and "Yedi İklim" sets according to the areas they are known for?

- What is the rate and form of personality given in the "İstanbul" and "Yedi İklim" sets at basic (A1A2), intermediate (B1-B2) and advanced (C1-C2) levels? 


\section{Model Of The Research}

As the study aims to identify the personalities in the textbooks and to reveal the way they are handled, the current situation was tried to be described by scanning the textbooks. Within this scope, in the research, document analysis, one of the qualitative research techniques, was used. Bowen (2009: 27) defines document analysis as a systematic process used to analyze or evaluate printed and electronic (computer-based and transmitted over the internet) materials, and as with other analytical methods in qualitative research, document analysis underlines that it requires the analysis and interpretation of data in order to make sense out of, gain understanding and develop experimental information. In this study, the textbooks used in the related field are examined in terms of personalities in the context of cultural transfer, and it is tried to reveal what kind of understanding is aimed in the selection of personality in the textbooks.

\section{Conclusion, Discussion And Suggestions}

In this study, which was designed to reveal whether personalities are included in the textbooks in accordance with a particular system and understanding, it was found that 97 personalities were included in the "İstanbul" set and 164 personalities in the "Yedi İklim" set in different categories in the sum of all levels of both textbooks. Considering the findings regarding the ways of giving personalities in the textbooks, the conclusions reached are as follows: 66 of the 97 personalities in the "İstanbul" set (68.04\%) and 67 of the 164 personalities in the "Yedi İklim" set $(40.85 \%)$ are given as names. The characteristics of 17 people $(17.52 \%)$ in the "İstanbul" set and 38 people $(62.32 \%)$ in the "Yedi İklim" set are included in the text. In the "İstanbul" set, 20 personalities (13.4\%) and in the "Yedi İklim" set, 59 personalities were processed in the context of the text. When the related ratios are considered, the fact that the difference between the two sets is so high indicates that both sets are created without considering a criterion in the context of the component of persons.

When the findings obtained from the research are compared and interpreted in terms of both sets, although the frequency and the way of giving the personalities in the "Yedi İklim" textbooks at A1, A2, B1 and B2 levels is higher than the "İstanbul" book, at $\mathrm{C} 1$ and $\mathrm{C} 2$ levels, the frequency of giving personalities in both books is very close to each other. If an assessment is made based on the way the personalities are given, while "Yedi İklim" books only include personalities through reading and listening skills, it is concluded that the book "İstanbul" includes personalities on all abilities, especially at $\mathrm{C} 1$ and $\mathrm{C} 1+$ levels. It is very important to give personalities that are included in the "İstanbul" set not only through listening and reading skills, but also through speaking and writing skills. In both sets, when the personalities they included are considered in terms of gender, it has been determined that there is very little room for women. This is a very important deficiency for textbooks.

Considering the studies examining the textbooks in the literature within the context of the cultural content they contain and the findings of this study, it is seen that there is not a certain systematic and understanding in the sense of the component of persons while creating textbooks. Within this framework, the results of this study and the studies conducted by Şimşek (2018), Gürsoy and Güleç (2015), Özyurt Gülen (2019), Erdal et al. (2019: 246) are similar. In addition to these results, it has been determined that there are very few female personalities in textbooks compared to men. However, considering the importance given by Turkish society to women and the success of women in society, it can be said that this situation emerging in textbooks is a significant deficiency in terms of cultural transfer. In this context, there is a deficiency in the context of the criteria "Is there equal importance for women and men in every area of the textbook?" (by Liu, 2016: 843), which is one of the eight criteria proposed by Cunningsworth (1995) for evaluating cultural content. Based on all these results, various studies should be conducted on who should be the personalities to be included in the textbooks, and in these studies, the personalities that should be included in the textbooks should be determined consulting the opinion of the people come to the fore with their cultural identity in Turkey and the ideas of the teachers, academics etc. who teach in the field. Attention should be paid to giving personalities that will be included in the textbooks written about teaching Turkish as a foreign language in a thematic/categorical way. When placing personalities in textbooks, it should be noted that there is an equal distribution in every field (history, politics, literature, cinema, etc.) as much as possible.

Keywords: Turkish Teaching as a Foreign Langauge, Course books, Personalities. 
Öz: Araştırmanın amacı, yabancı dil olarak Türkçe öğretiminde kullanılan ders kitaplarındaki şahsiyetleri tespit etmek, bu şahsiyetlerin ders kitaplarında ne sıklıkla ve ne şekilde işlendiğini ortaya çıkarmaktır. Çalışmada nitel araştırma yöntemlerinden biri olan doküman analizi kullanılmıştır. Çalışma materyali olarak Yedi İklim ve İstanbul Yabancılar İçin Türkçe setleri seçilmiştir. Araştırma sonucunda her iki setin bütün seviyelerinin toplamında sporcu, sanatçı, yazar, ozan, şair, din adamı, bilim insanı, senarist, iş insanı, hattat, yönetmen, gazeteci, devlet adamı kategorilerinde olmak üzere İstanbul setinde 97, Yedi İklim'de ise 164 şahsiyete yer verildiği tespit edilmiştir. A1, A2, B1 ve B2 seviyelerinde Yedi İklim setinde şahsiyetlerin veriliş şekli ve oranı İstanbul setinden fazla olsa da $\mathrm{C} 1$ ve $\mathrm{C} 2$ seviyelerinde her iki kitabın şahsiyetleri veriş oranı birbirine çok yakındır. Ders kitaplarında yer alan şahsiyetlerin veriliş şekline ilişkin ulaşılan bulgular şu şekildedir: İstanbul setinde yer alan 97 şahsiyetin 66'sına (\%68,04), Yedi İklim'de yer alan 164 şahsiyetin 67 'sine $(\% 40,85)$ isim olarak yer verilmiştir. İstanbul setinde $17(\% 17,52)$, Yedi İklim'de ise $38(\% 62,32)$ şahsiyetin özelliklerine yer verilmiştir. İstanbul setinde $20(\% 13,4)$, Yedi İklim setinde ise 59 şahsiyet, metin bağlamında işlenmiştir. Ayrıca çalışmada, İstanbul setinde yer verilen şahsiyetlerin sadece dinleme ve okuma becerisi üzerinden değil, konuşma ve yazma becerilerinin üzerinden de verildiği tespit edilmiştir. Her iki sete, yer verdikleri şahsiyetlere cinsiyet bağlamında bakıldığında kadın şahsiyetlere çok az yer verildiği görülmektedir. $\mathrm{Bu}$ da ders kitapları açısından oldukça önemli bir eksiklik olarak değerlendirilmektedir. Ulaşılan bulgular, hem iki set arasındaki şahsiyetlerin veriliş biçimi ve oranı arasındaki farkın fazla olması hem de özellikle kadın şahsiyetlerin erkeklere göre çok az olması, ilgili setlerde şahsiyetlere sistematik bir yaklaşımla yer verilmediği sonucunu ortaya çıkarmıştır. Tüm bu sonuçlardan hareket ile ders kitaplarında yer alacak şahsiyetlerin kimler olması gerektiğine yönelik çeşitli çalışmalar yapılmalı ve bu çalışmalarda, Türkiye'de kültürel kimliği ile ön plana çıkmış insanların, alanda ders veren öğretmenlerin, akademisyenlerin vb. görüşlerine başvurularak ders kitaplarında yer verilmesi gereken şahsiyetler belirlenmelidir.

Anahtar Kelimeler: Yabancı dil olarak Türkçe öğretimi, ders kitapları, şahsiyetler.

\section{Giriş}

Yabancı dil öğrenimi ihtiyacı ve arzusu, dünyadaki teknolojik gelişmelere ve bu gelişmelerin ortaya çıkardığı iletişim kurma ihtiyacına bağlı olarak giderek artmaktadır. Geçmişte öğrenilmek istenen dilin sadece dil bilgisi kurallarını bilmek, hedef dilden ana dile, ana dilden hedef dile yönelik çeviri yapabilmek yeterli görülmekteyken bugün bu durum yabancı dil öğrenme ihtiyacını karşılayamamaktadır. Bu nedenle, bir yabancı dil bilmenin yeterlikleri arasında öne çıkan ilk iki durumun birincisi, hedef dili ana dili olarak konuşanlarla iletişime geçebilmek; ikincisi ise o dili konuşanların kültürünü öğrenmektir. "Dolayısıyla iletişim eylemi temelde bir dilbilimsel mesaj alışverişi olarak değil, daha çok toplumsal kurallar ve işlevlerin daha önce üzerinde anlaşıldığı veya bilindiği kadarıyla dil kullanımının önemli bir rol oynadığı sosyal olarak anlamlı bir bölüm olarak görülür." (Asemota, 2015: 16). Bu bağlamda öğrenilmek istenilen hedef dilde doğru ve etkili bir iletişim kurulabilmesi için ise o toplumun kültürünün de bilinmesi gerekmektedir. Bu nedenle özellikle yabancı dil öğretiminde kültür aktarımı konusu, geçmişten bugüne tartışılan en temel konulardan biri olmuştur. Çünkü Spencer-Oatey (2012)'in de belirtiği gibi kültür, tanımlanması zor bir terimdir ve 1952'de Amerikalı antropologlar Kroeber ve Kluckhohn, kültür kavramlarını ve tanımlarını eleştirel olarak gözden geçirmiş, 164 farklı tanımın bir listesini derlemişlerdir. Bu bağlamda Türk Dil Kurumu güncel sözlükte kültür, "tarihsel, toplumsal gelişme süreci içinde yaratılan bütün maddi ve manevi değerler ile bunları yaratmada, sonraki nesillere iletmede kullanılan, insanın doğal ve toplumsal çevresine egemenliğinin ölçüsünü gösteren araçların bütünü” olarak tanımlanmaktadır. Kültüre ait diğer tanımlamalar ise şöyledir: "Kültür ... bilgi, inanç, sanat, ahlak, hukuk, gelenek ve insanın toplumun bir üyesi olarak edinmiş olduğu diğer yetenek ve alışkanlıkları içeren karmaşık bütündür." (Tyler, 1870’den akt. Avruch 1998: 6). "Kültür, yalnız bir ulusun din, ahlak, hukuk, us, estetik, dil, iktisat, felsefe ve fenle ilgili yaşayışlarının uyumlu bir toplamıdır." (Gökalp, 1997:25). "Bir grup insan tarafından paylaşılan, ancak her birey için farklı olan, bir nesilden diğerine iletilen tutumlar, değerler, inançlar ve davranışlar kümesi." (Matsumoto, 1996:16). Her üç tanımın ortak özelliğine bakıldığında kültürün karışık bir bütün olması, toplumun 
her bireyini ilgilendirmesi ve nesilden nesile aktarılması nedeniyle ne kadar önemli bir olgu olduğu anlaşılmaktadır. Bu bağlamda Han ve Zhang (2020: 449) başka bir kültürü tanımanın oldukça zor bir iş olduğunu, başka bir kültürde uygun davranmanın ise daha zor bir iş olduğunu belirterek yabancı dil öğreticilerinin öğrencileri kültürel farklılıklara alıştırmak, öğrencinin kendi kültürünü aşmasına ve olayları hedef kültürün üyeleri gibi görmesine yardımcı olmak, çeşitli hedef sınıf uygulamaları yoluyla dili ve kültürü anlamanın ayrılmazlığını vurgulamak, iletişim kültürünü vurgulamak ve öğrencilerin yabancılarla başarılı iletişim kurmalarını sağlamak gibi kültür aktarımı bağlamında kendi dil sınıflarında öğretecekleri en az dört amacın olması gerekliliğini belirtir. $\mathrm{Bu}$ da dil öğretiminde kültür aktarımının önemini açıkça ortaya koyar.

Dil öğretim sürecinde kültür aktarımının/ öğretiminin önemini Türkçede, "İnsan tanımadığının düşmanıdır." atasözü ile açıklayan ve kültür aktarımından beklenen temel şeyin öteki kavramının oluşturduğu negatif çağrışımı yıkmak ve ötekini daha yakından tanımak" olarak açıklayan Demir (2014: 56), kültür aktarımının ne kadar önemli olduğunu açıkça gözler önüne sermektedir. Bu bağlamda Koşger (2015: 411) gerçek iletişim durumlarında, bir toplumun kültürü içinde oluşmuş birtakım bileşenler (ekonomi, siyaset, tarih, gelenekler, mizah vs. gibi farklı boyutları içine alan kültür, çeşitli kısaltmalar, deyimler, atasözleri gibi kullanımların yanı sıra jest ve mimikler gibi söz dışı iletişim bileşenlerini de kapsamaktadır) olduğunu ve bu bağlamda, yabancı dil öğretiminde hedef dilin kültürünün de farklı boyutlarıyla öğrencilere aktarılması gerektiğini belirtir. $\mathrm{Bu}$ da kültürün birden fazla bileşeni içerisinde barındıran karmaşık bir olgu olduğunu gösterir. Kültürü, "ortak bir ürün setiyle ilişkili, dünyaya ilişkin ortak bir perspektif kümesine dayanan ve belirli sosyal bağlamlar içinde yer alan ortak bir uygulama grubundan oluşan bir grup insanın gelişen yaşam biçimi” olarak tanımlayan Moran (2001: 24), Brody (2003) ile Bennett, Bennett ve Allen (2003) tarafindan ürünler, uygulamalar ve görüşler olarak belirlenen kültürel boyutlara topluluk ve kişileri de eklemiş ve ders kitaplarında bu bileşenlerin tamamına yer verilmesini savunmuştur. $\mathrm{Bu}$ bağlamda Moran (2001) kişilerin, kendi toplumlarının kültürünü temsil etmek için kanal görevi gördüğünün ve ders kitaplarında kişiler bileşenine yer verilmesinin öğrencilerin uluslararası kültürünü geliştirmek için önemli bir faktör olduğunun altını çizer ve oluşturduğu beş boyutlu kültürel modeli aşağıdaki gibi betimler:

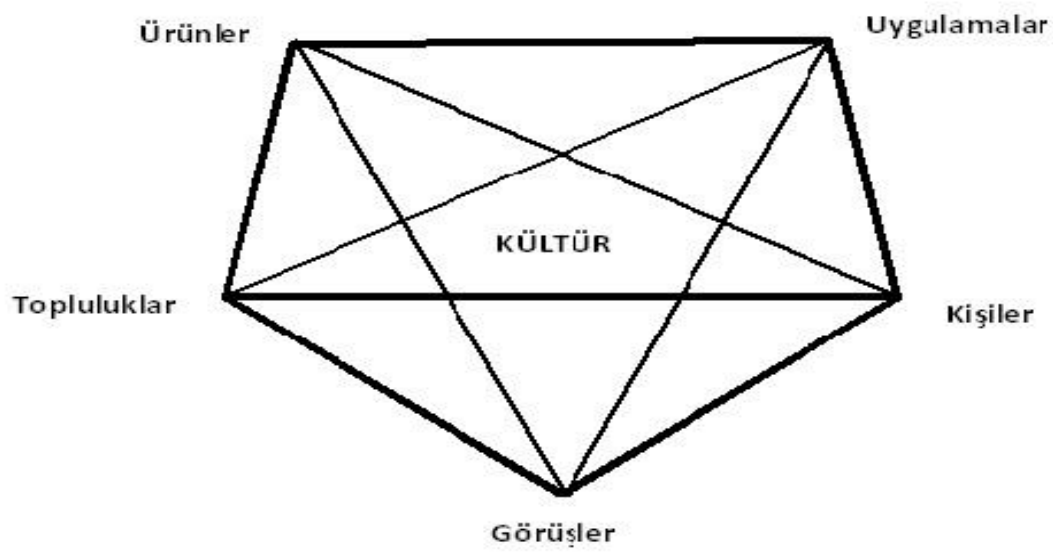

Kaynak: Moran (2001: 24)

Şekil 1: Kültür'ün Beş Bileşeni

Moran, tarafından yukarıda verilen kültürün beş bileşeni ve bu bileşenlerin içerikleri şöyledir: Ürünler (örn. araçlar, gıda, kıyafetler), uygulamalar (sözel ve sözel olmayan dil, eylemler 
ve etkileşimler, tabular), görüşler (değerler, inançlar), topluluklar (1rk, cinsiyet, din, vb.) ve kişiler (bireyler).

Yukarıdaki bilgiler kapsamında Peterson (2004), Chen (2004) ve Lee (2009), kültürü, "Büyük "K" ve küçük "k" olmak üzere ikiye ayırmışlardır. Lee (2009: 78) toplumunun sanatı, tarihi, coğrafyası, iş dünyası, eğitimi, festivalleri ve gelenekleri büyük " $K$ " kültürün altında; topluma ait sosyo-kültürel değerleri, normları, günlük rutinleri, yaşam tarzını, yemekleri vb. ise küçük " $\mathrm{k}$ " kültürün içerinde sınıflandırmıştır. Bu bağlamda bu iki kültürün altındaki unsurlara bakıldığında özellikle büyük kültürün $(\mathrm{K})$ ders kitaplarında aktarımda genellikle şahsiyetlerin kullanıldığ görülmektedir. Güleç ve Gürsoy (2015)'un da belirttiği üzere bir topluma ait sanat, edebiyat, tarih, müzik, spor gibi kültürel ögeler genelde bu alanlarda belirli bir üne kavuşmuş ve o alanla toplumla özdeşleşmiş bireyler üzerinden verilmektedir. Bu da ders kitaplarında hem kültür bileşenlerinden biri olarak hem de büyük kültürün aktarımında bir araç olarak kişilere (şahsiyetlere) yer verilmesi gerektiğini açıkça ortaya çıkarmaktadır.

$\mathrm{Bu}$ çalışmanın konusu olan ders kitaplarındaki şahsiyetler, "kişiler", belirli bir kültürel kimlikle/toplulukla eşleştirilen bireyler (Şimşek, 2018: 304) olarak ele alınmaktadır. Çünkü ders kitabında verilen kişinin, kaynak toplum, hedef kültürün toplumu veya uluslararası toplumda bir kimliğinin olması gerekmektedir. Bu da doğal olarak ders kitaplarında kimlere ne oranda ve nasıl yer verileceğinin dikkate alınması gerekliliğini ortaya koyar. Çünkü Kim ve Peak (2013: 101-102) kültür bileşenlerinden biri olan kişiler boyutunun hedef kültürü anlamada önemli bir faktör olduğunu belirtir. Fişekçioğlu (2019: 143) da AOÖÇ metninde, önemli tarihi ve ünlü kişilerin sosyokültürel bilginin bileşenleri olarak yer aldığının altını çizer. Aynı şekilde Okur ve Keskin (2013) de ders kitaplarında yer alan kültür ögelerini tespit ederken "kişiler arası ilişkiler" ögesinin alt ögesi olarak "kişiler"i almıştır. Buna ek olarak AOÖÇ metninde 7 başlık altında verilen sosyo kültürel ögelere bakıldığında aslında bu ögelerin verilişinde de (sanat, müzük, edebiyat, tarih, hobiler, meslek grupları vb.) doğrudan veya dolaylı olarak şahsiyetlerin üzerinden bir anlatım yapıldığı (Gürsoy ve Güleç, 2015) görülmektedir. Bu da doğal olarak ders kitapları kültür aktarımı bağlamında incelenirken "kişiler" bileşenin de dikkate alınması gerekliliğini ortaya çıkarmıştır. Bu bağlamda alanyazın incelendiğinde (Lappalainen, 2011; Çelik ve Erbay, 2013; Andarap, 2015; Kim ve Peak, 2015; Dewi, 2016; Ulum, 2018; Şimşek, 2018; Almalı, 2019; Erdal vd., 2019; Kılıç, 2019, Özyurt Gülen, 2019) yabancı dil öğretiminde kullanılan ders kitapları kültür aktarımı bağlamında incelenirken ölçüt olarak "kişiler bileşeni”nin ayrıca bir kategori olarak ele alındığı görülmektedir. Ders kitaplarında kültür bileşenlerinden biri olan kişilere yer verilmesi gerekliliğine ek olarak bunun oranının ve veriliş biçimin nasıl olması gerektiği de ayrıca tartışılması gereken bir husustur. Çünkü ders kitaplarında kaynak kültür, hedef kültür, uluslararası kültür ve kültürlerarası etkileşim gibi kültürün ana kategorilerinin (Chao, 2011: 89) tamamına belirli oranlarda yer verilmesi gerekmektedir. Fişekçioğlu (2019: 5)'nun da vurguladığı gibi yabancı dil olarak Türkçe öğretiminde, Türk kültürüne ait ögelerin aktarılmaması düşünülemez. Bu aktarımın da belirli bir yöntem, ölçünlü bir bakış açısıyla yapılması, Türkçeyi öğrenenlere hem öğrenme sürecinde hem Türkçeyi çözümlemede yardımcı olacak hem de kültür aktarımı yoluyla Türk kültürüne ait tüm kültürel şifrelerin dünyaya yayılmasına neden olacaktır. Bu nedenle ders kitaplarında kültür aktarımından beklenen temel anlayış, hedef kültürünün istenilen düzeyde aktarılması ve kaynak kültür ile uluslararası kültüre de yer vererek kültürlerarası etkileşimin gerçekleşmesine katkıda bulunmasıdır. Bu görüşe destek olarak Elomaa (2009: 109-110) ders kitaplarının öğrencilerin hedef kültürlere karşı tutumlarını etkileme gücüne sahip oldukları için kültürlerarası öğrenme ve öğretme ilkelerinin geliştirilmesinde kritik bir rolü olduğunu belirtir (akt. Lappalainen, 2011: 20). Fakat Şimşek (2018: 307)'in de belirttiği gibi ders kitapları kültür aktarımı bağlamında ele alındığında kültürel içeriğin yapılandırılmasında herkesçe izlenecek kültürel bir izlencenin bulunmaması en büyük sorun olarak karşımıza çıkmaktadır. Bu da hem ders kitaplarının kendilerine ait sınırlılıklarının olması hem de çok geniş ve renkli bir yelpazeye sahip olan kültür içinde üst başlıkta dil, din, gelenek-görenek, yeme-içme, sanat, tarih, hukuk, mimari, vb. yer alırken 
her bir başlık altında da onlarca alt başlık yer alması nedeni ile yabancı dil öğretiminde kullanılan ders kitaplarında topluma ait bütün kültürün aktarımı mümkün olmamaktadır. $\mathrm{Bu}$ da kültür aktarımında belirli bir yol ve standart ölçütler belirlenmesinin gerekliliğini açıkça ortya koymaktadır. İlgili alanyazında ders kitaplarındaki metin bağlamlı kültür aktarımına yönelik her ne kadar bazı araştırmacılar tarafından (Huhn, 1978; Risager, 1991; Byram vd. 1994; Cunningsworth, 1995; Sercu, 1998; Kılıçkaya, 2004; Reimann, 2009, akt Liu, 2016:143-144) ölçütler belirlense de bu ölçütlerin de kendi içerisinde bir tutarlığının olmadığı görülmektedir. Bu durumda da ders kitaplarında kültür aktarımı bağlamında çeşitli eksiklikler ve farklılıklar ortaya çıkmaktadır. Oysaki Lappalainen (2011: 20)'in de belirttiği gibi ders kitaplarından beklenen ideal amaç, ders kitabının, hedef ülkelerin kültürünü, dilini ve zihniyetini ilginç ve motive edici bir şekilde sunarak öğrencilerin hedef kültürle ilgilenmesini sağlamaktır. Fakat hem kültürel içeriğin yapılandırılmasında herkesçe izlenecek kültürel bir izlencenin bulunmaması hem de kültür kavramının içerisinde birçok bileşenin olması, ders kitaplarında kültür aktarımı yazarların kişisel deneyimleri ve kültüre bakış açıları çerçevesinde gerçekleşmekle birlikte bu da sonuç olarak ders kitaplarında kültür aktarımı bağlamında bir standartın olmamasına neden olmaktadır. Bu durum ders kitaplarında yer verilen ve Moran (2001)'ın beş kültür bileşeninden biri olan kişiler (şahsiyetler) bağlamında da geçerli bir durumdur. Çünkü ders kitaplarında yer verilecek şahsiyetlerin kimler olması ve hangi bağlamda ele alınmaları noktasında belirlenmiş bir ölçüt bulunmamaktadır. Oysaki Kılcan, Akbaba ve Gülbudak (2017: 550)'ın da belirttiği gibi "eğitim sistemleri, ünlü şahsiyetlerin insanlığa sağladığı katkıyı okul çatısı altındaki öğrencilere aktarmakta, onları örnek alınacak birer şahsiyet olarak göstererek, insanlığa yapmış oldukları katkının gelecek nesillerde de devam etmesini hedeflemektedir. Bu bağlamda, Türkiye Cumhuriyeti eğitim sisteminde yer alan ders müfredatları, gerek kendi geçmişine ait olan ünlü şahsiyetlerin gerekse yabancı şahsiyetlerin kişilik özellikleri ve insanlığa sağladıkları faydalara yer vermekte, bunların öğrencilere kazandırılmasını amaçlamaktadır." Bu husus yabancı dil öğretimi içinde aynı şekilde geçerli olmalıdır. Çünkü dil öğretiminde hedef kitlenin başarısını etkileyen en temel faktörlerden biri de öğrenilen dile, ülkeye, kültüre vb. olan yakınlık veya meraktır. Bu noktada ise bunu sağlayabilecek en temel materyal ders kitaplarıdır.

"Ders kitapları sınıflarda dil öğrenmenin ayrılmaz bir parçasıdır. Günümüzde pek çok alternatif ögretim materyali olmasına rağmen, ders kitapları, dersliklerdeki içerik, yöntem ve yaklaşımlar, eğitim felsefesi, dilsel ve kültürel bilgileri belirlemede hâlâ çok önemlidir." (Yılmaz, 2012: 2753). Öğretmenlerin çoğu genellikle ders kitaplarına bağlıdır. Çünkü kitaplar, dersi şekillendiren içerik ve etkinlikleri öğretmenlere sunan en temel araçtır. (Byrd, 2001: 415). Ders kitapları, zaman ve paradan tasarruf etmek için eklektik alternatiflerdir. Öğretmenin açıklamalarından daha verimli olabilecek resimler ve grafik malzemeleri ve sınıfa getirilmesi zor olabilecek her türlü nesneyi içerdikleri için yabancı dil öğretiminde oldukça önemlidir (González, 2006: 104). Ders kitaplarının büyük kısmı iletişimsel eğilimlerin önerdiği mevcut teorilere dayanan eklektik bir yaklaşıma sahip olduğu için (Rodríguez, 2010: 26), çoğu öğretmen için büyük bir zorunluluktur. "Gramer bilgileri, metinler, sözcük dağarcığı ve kültürel özellikleri hedef dil öğrenicisine aktarmada en büyük araç olan ders kitapları, süreçte hem öğretmen hem de öğrencinin hayati bir uzvu gibidir. Taşıdığı bu ehemmiyete istinaden ders kitapları dil öğretimi açısından sürecin lokomotifi görevindedir. Bu çerçevede hedef dili öğrenenler için o dilin muhtevası, toplumsal özellikleri ve yaşayışa etkisi çok büyük bir öneme sahiptir (Şimşek, 2016: 6). "Uygun ders kitapları, deneyimsiz öğretmenlerin yabancılara Türkçe öğretimi ders müfredatının içeriğini tanımaları ve bu müfredatı farklı öğrencilere çeşitli düzeylerde öğretebilmeleri açısından çok yararlı olabilir (Özdemir, 2013: 2051). Yabancı dil öğretiminde temel dil becerilerinin kazandırılmasında çeşitli materyallerden yararlanılır, ancak bu materyaller içerisinde en çok kullanılanın ders kitaplarıdır (Karababa, 2009: 276). Bu görüşlere bakıldığında eğitimin vazgeçilmez bir ögesi olan ders kitaplarının yabancı dil öğretiminde de oldukça önemli olduğu görülmektedir. Sawyer (2008) de yabancı dil ders kitaplarının, öğrencilerin sadece eğitimli değil, aynı zamanda farklı beceriler öğrenerek yaşam için hazırlanacak şekilde tasarlanması gerektiğini belirtir. Bu da hedef dilin sadece 
dil bilgisini bilmenin yeterli olmayacağının en önemli kanıtıdır. $\mathrm{Bu}$ nedenle ders kitapları hazırlanırken dil öğrenicilerin etkili iletişim kurabilecekleri yeterliklere ulaşmalarını destekleyecek içerikte etkinliklere yer verilmesi oldukça elzemdir. Byram (1997: 22) da yabancı dil öğretiminin kendisini sadece iletişim için dilbilimsel yeterliliğin pratik sorularıyla değil, aynı zamanda dil ile belirli bir grubun kültürel uygulamaları ve inançları arasındaki ilişkiyle de ilgilendirmesi gerektiğini belirtir. Yabancı dilde yetkinliğin kültürel uygulamaların edinilmesini ve tanınmasını da ima ettiğini kabul etmek esastır. Bu nedenle, Byram'in önerdiği en eksiksiz terim kültürlerarası iletişimsel yeterliliktir (Rodríguez, 2010: 24).

Ders kitaplarında kültür aktarımı ve kültürlerarası iletişim ise yabancı dil öğretimi alanında üzerinde ayrıca durulan konuların başında gelmektedir. Çünkü hedef dilde iletişimin sağlıklı kurulabilmesi için dilin kullanıldığı kültürün bilinmesi gerekmektedir. Bu görüşü Bölükbaş ve Keskin (2010: 221) yabanc1 dil öğretiminde kültürel ögelerin aktarılmasının dil öğrenme sürecini olumlu yönde etkilediğini belirterek destekler. Aynı şekilde İşcan ve Yassıtaş (2018: 47) da "yabancı dil öğretimi, yalnızca hedef dilin dil bilgisi ile kelimelerini öğretmek ve temel dil becerilerini kazandırmak değil, aynı zamanda o dilin kültürünün de öğretimidir. Çünkü yabancı bir dil her zaman beraberinde yabancı bir kültürü de getirir." görüşü ile hedef kültürü öğrenmenin ve öğretmenin önemine değinir. Türkçe öğrenen kişi sadece dili öğrenmez, aynı zamanda örf ve âdetleri de öğrenir. $\mathrm{Bu}$ nedenle öğretici hangi yöntemi kullanırsa kullansın öğreniciye dil unsurlarının yanı sıra kültür unsurlarını da vermelidir (Çangal, 2012: 13). Gün, Akkaya ve Kara (2014: 4), yabancılara Türkçe öğretiminde ders kitaplarının önemini şöyle belirtir: "Yabancılara Türkçe öğretiminin önemli bir diğer yanı kültür aktarımına olanak sağlamasıdır. Türk kültürünün yabancılara aktarımında en önemli unsurların öğretmenler ve ders kitapları olduğu dikkate alınacak olursa ders kitaplarının yabancılara Türkçe öğretimi açısından ayrı bir öneme sahip olduğu söylenebilir." Moralı ve Göçer (2019: 1117) de, "ders kitaplarında yer alan metinler, görseller ve farklı unsurlar öğrencilerin Türk kültürünü keşfetmesine birer uyaran olarak zemin hazırlamakta" olduğunu vurgular. Bu bilgiler bağlamında yabancı dil olarak Türkçe öğretimi alanında kullanılan veya kullanılmak üzere hazırlanan ders kitaplarından beklenti ise Türk kültürünü öğretici içerikte olmasıdır. Çünkü Okur (2012: 200)'un da belirttiği üzere Türkler hem İslamiyet'ten önce hem de İslamiyet'ten sonra kültürel anlamda pek çok değerler bırakmıştır. Bu değerler; somut bir yapı, kavramsal (soyut) bir miras olduğu gibi şahsiyetler olarak da karşımıza çıkmaktadır. Bu şahsiyetler, gerilerinde pek çok eser bıraktıkları gibi, fikirleri ile de geniş toplulukları etkilemişler ve bir akım oluşturmuşlardır. $\mathrm{Bu}$ da ders kitaplarında kültür aktarımı bağlamında kullanacak birçok şahsiyete sahip olduğumuzu gösteririr. Bu bağlamda İmik Tanyıldızı (2011: 117) "kültürü oluşturan değerlerimizin unutulmaması ve gelecek kuşaklara aktarılması için Hacı Bektaş Velî, Mevlâna, Yunus Emre gibi düşünürlerimizle ilgili çalışmalara daha fazla yer vermesi gerekmektedir" ifadesi ile kültür aktarımında belirli bir kimliğe sahip şahsiyetlerin önemini açıkça ortaya koymuştur. Bu nedenle yabancı dil olarak Türkçe öğretilen hedef kitleye de kültür aktarımında bu hassasiyeti taşımak ve ders kitaplarını bu bağlamda hazırlamak şüphesiz kültür aktarımını daha başarılı kılacaktır. Çünkü Özkan (2014: 244) kültürün oluşmasında toplum içerisinden çıkmış önemli kişilerin büyük bir etkisi söz konusu olduğunu, bireylerin hayata bakışlarında, düşünce biçimlerinde ve hatta yaşam tarzlarında bu tür kişilerin yapıp ettikleri, söyledikleri önemli belirleyiciler olarak karşımıza çıktığına işaret eder. Fakat Kalenderoğlu (2015: 82) özellikle ders kitabı yazarlarının veya komisyonların- istisnalar hariç -kültür aktarımı hususunu öncelikler arasına almadıklarını belirtmektedir. Demir (2014) de ilgili ders kitaplarında kültür aktarımının bir sistematiğinin olmadığını vurgulamaktadır. Bu nedenle ilgili konu bağlamında yapılan birçok çalışmada ders kitaplarında kültür aktarımının yetersiz veya eksik olduğu (Demir ve Açık, 2011; Karababa ve Üstünsoy Taşkın, 2012; Okur ve Keskin, 2013; Ökten ve Kavanoz, 2014; Kalenderoğlu, 2015; Kutlu, 2015; Erdil, 2018; Şimşek, 2018) görülmektedir. Tüm bu bilgilerden hareketle alan yazın tarandığında yabancı dil olarak Türkçe öğretiminde kullanılan ders kitaplarında kültür aktarımı ve kültürel ögelerin tespiti ile ilgili (Toprak, 2011; Demir, 2014; Akbulut ve Yaylı, 2015; Tanrıverdi ve Tün, 2016; Ömeroğlu, 2016; Şimşek, 2016; Göçer, 2017; Kalenderoğlu, 2017;

Turkish Studies - Education, 15(3) 
Barcın, 2018; 2019; Baskın, 2018; Boztilki, 2018; Yaylı ve Yayl1, 2018; Iltar ve Dündar, 2018; Çetinoğlu ve Güllülü, 2018; Hasırcı, 2019; Akkoyunlu, 2019; Biçer ve Batdı, 2019; Mutlu ve Şet, 2020) birçok çalışma yapılmıştır fakat doğrudan ders kitaplarında kültür bileşenlerinden biri olan "kişiler"in tespiti bağlamında bir çalışma olmadığı için bu çalışmanın özellikle ders kitabı yazarları ve Türkçe öğreticileri için kültür aktarımında yer verilecek kişilerin kimler olması gerektiği, bunların ders kitaplarında nasıl işleneceği konusunda yol gösterici olacağı düşünülmektedir.

\section{Araştırmanın Amacı}

$\mathrm{Bu}$ araştırmanın amacı, yabancı dil olarak Türkçe öğretiminde kullanılan ders kitaplarında hangi şahsiyetlere yer verildiğini belirlemektir. Araştırmanın alt amaçları aşağıda verilmiştir.

- İstanbul ve Yedi İklim setlerinde hangi şahsiyetlere yer verilmiştir?

- İstanbul ve Yedi İklim setlerinde verilen şahsiyetlerin tanındıkları alanlara göre dağılımları nasildır?

- İstanbul ve Yedi İklim setlerinde şahsiyetlerin temel (A1-A2), orta (B1-B2) ve ileri düzeydeki (C1-C2) veriliş oranı ve şekli nasıldır?

\section{Yöntem}

\section{Araştırmanın Modeli}

Çalışma, ders kitaplarında yer alan şahsiyetleri tespit etmeyi ve bunların ele alınış biçimlerini ortaya çıkarmayı amaçladığ 1 için ders kitapları taranarak mevcut durum betimlenmeye çalışılmıştır. Bu kapsamda araştırmada, nitel araştırma tekniklerinden doküman analizi kullanılmıştır. Doküman analizini Bowen (2009:27) basılı ve elektronik (bilgisayar tabanlı ve internet üzerinden iletilen) materyalleri incelemek veya değerlendirmek için kullanılan sistematik bir süreç olarak tanımlar ve nitel araştırmadaki diğer analitik yöntemlerde olduğu gibi, doküman analizi de anlam çıkarmak, anlayış kazanmak ve deneysel bilgi geliştirmek için verilerin incelenmesini ve yorumlanmasını gerektirdiğinin altını çizer. Bu çalışmada da ilgili alanda kullanılan ders kitapları kültür aktarımı bağlamında yer verdiği şahsiyetler açısından incelenerek ders kitaplarında şahsiyet seçiminde nasıl bir anlayış amaçlandığ 1 ortaya çıkarılmaya çalışılmıştır.

\section{Verilerin Toplanması ve Analizi}

Bowen (2009: 32) doküman analizinin gözden geçirme (yüzeysel inceleme), okuma (ayrıntılı inceleme) ve yorumlamayı içeren bir süreç olduğunu belirtir. Araştırmaya konu olan "Yedi İklim Türkçe Yunus Emre Enstitüsü Türkçe Öğretim Seti Ders Kitabı" (Yedi İklim) ve "İstanbul Yabancılar İçin Türkçe Ders Kitabı" (İstanbul) kitaplarının bütün seviyeleri ilk aşamada taranarak şahsiyetlerin genel olarak hangi beceriler bağlamında nasıl verildiği konusu belirlenmiştir. Yapılan bu inceleme ile şahsiyetlerin bazılarının sadece isimlerine ve bazılarının da belirli özelliklerine yer verildiği, bazılarının ise metin bağlamında doğrudan işlendiği ortaya çıkarılmıştır. Bu nedenle ilgili tespit kapsamında incelemenin ikinci kısmı olan okuma aşamasında ilgili ders kitaplarındaki şahsiyetler;

- Sadece isim olarak yer verilenler,

- Metinde özelliklerine yer verilenler,

- Metin bağlamında işlenenler, şeklinde kodlanmıştır.

$\mathrm{Bu}$ incelemede bu tür bir kodlama kategorisinin geliştirilmesindeki amaç, Büyüköztürk vd. (2013: 242)'ün de belirttiği gibi, daha sonra yapılacak benzer çalışmalarda ve bu çalışmanın 
güvenirlik hesaplamalarında araştırmacıların aynı materyalleri incelediğinde aynı sonuçlara ulaşmalarını sağlayabilecek kadar kodlamanın açık olmasıdır. Bu kodlamalar ise içerik analizi ile yapılmıştır. İçerik analizinde Büyüköztürk vd. (2013: 243), araştırmacının açık içerik kullanarak kodlama yapabileceğini ve bunun yapılabilmesi için de incelenen dokümanda (resim, metin vb.) açık olarak görülebilecek bir kavramın belirlenmesi gerektiğini vurgular. Bu bağlamda incelenen setlerde yer alan şahsiyetlerin üç ölçüt bağlamında hangi becerilerde kaç kez geçtiği belirlenmiştir.

Kodlamalar, ders kitaplarından aşağıdaki gibi alınmıştır:

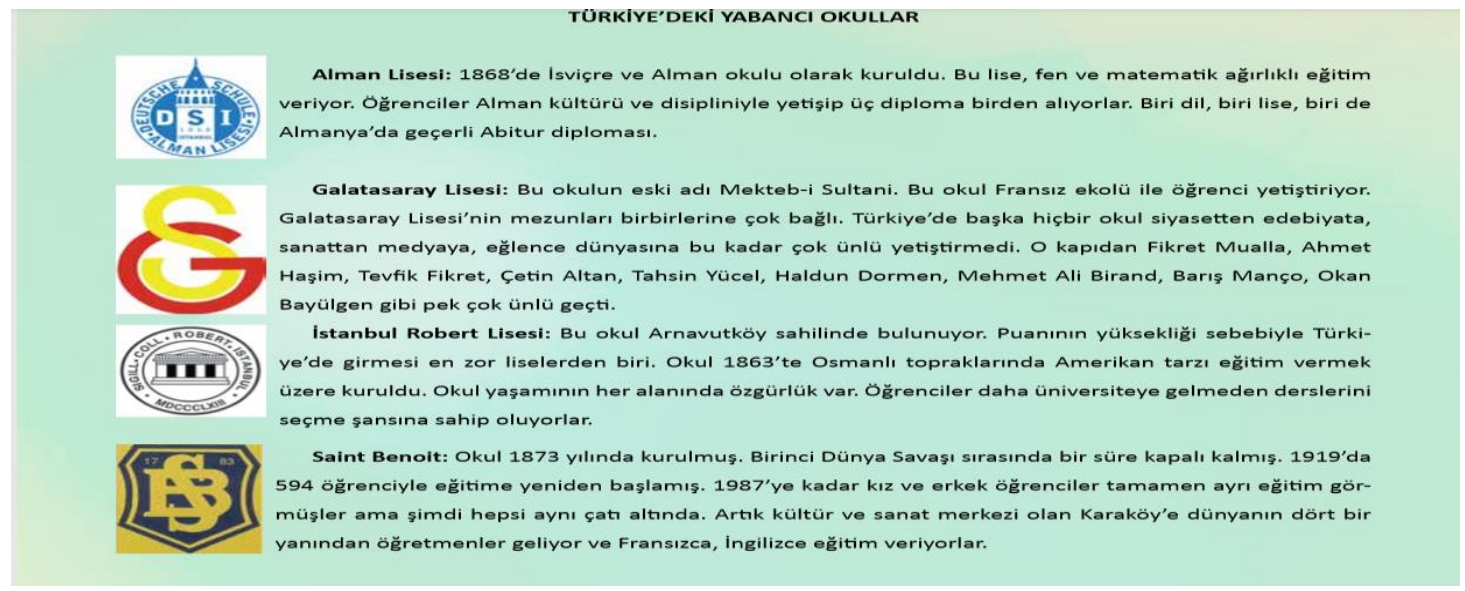

Görsel 1: Şahisyetlerin sadece isim olarak yer aldığı örnek metin

Kaynak: İstanbul B1 ders kitab1, s.62

Yukarıdaki metne bakıldığında Türkiye'de bulunan yabancı okulların tanıtıldığı görülmektedir. İlgili okullar tanıtılırken Ahmet Haşim, Barış Manço, Okan Bayülgen gibi ünlülerin de bu okullardan mezun oldukları bilgisi verilmiştir.

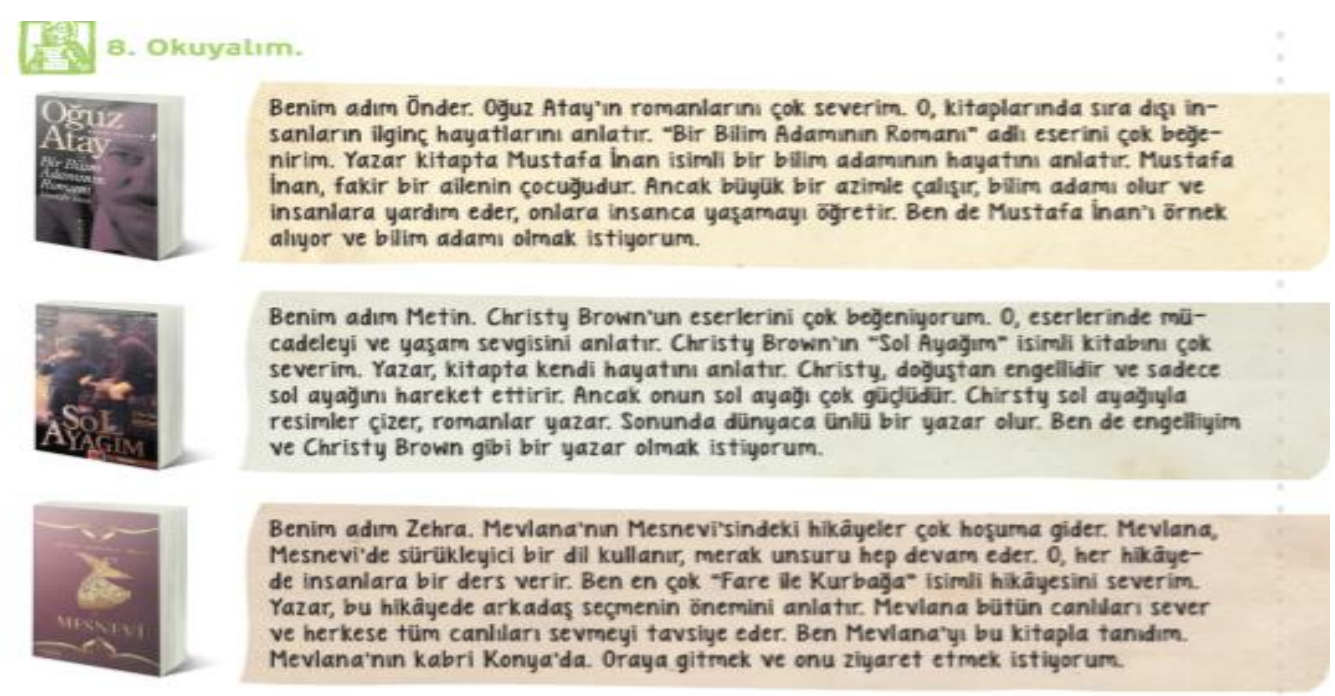

Görsel 2: Şahsiyetlerin özelliklerine yer verilen örnek metin

Kaynak: Yedi İklim A2 ders kitab1, s.52

Turkish Studies - Education, 15(3) 
Yukarıdaki görsele bakıldığında metinde Oğuz Atay'ın (1. paragraf) bazı özelliklerine yer verildiği (romanları çok sevdiği, Bilim adamı olmak istediği, Mustafa İnan'ı kendisine örnek aldığı vb.) görülmektedir.

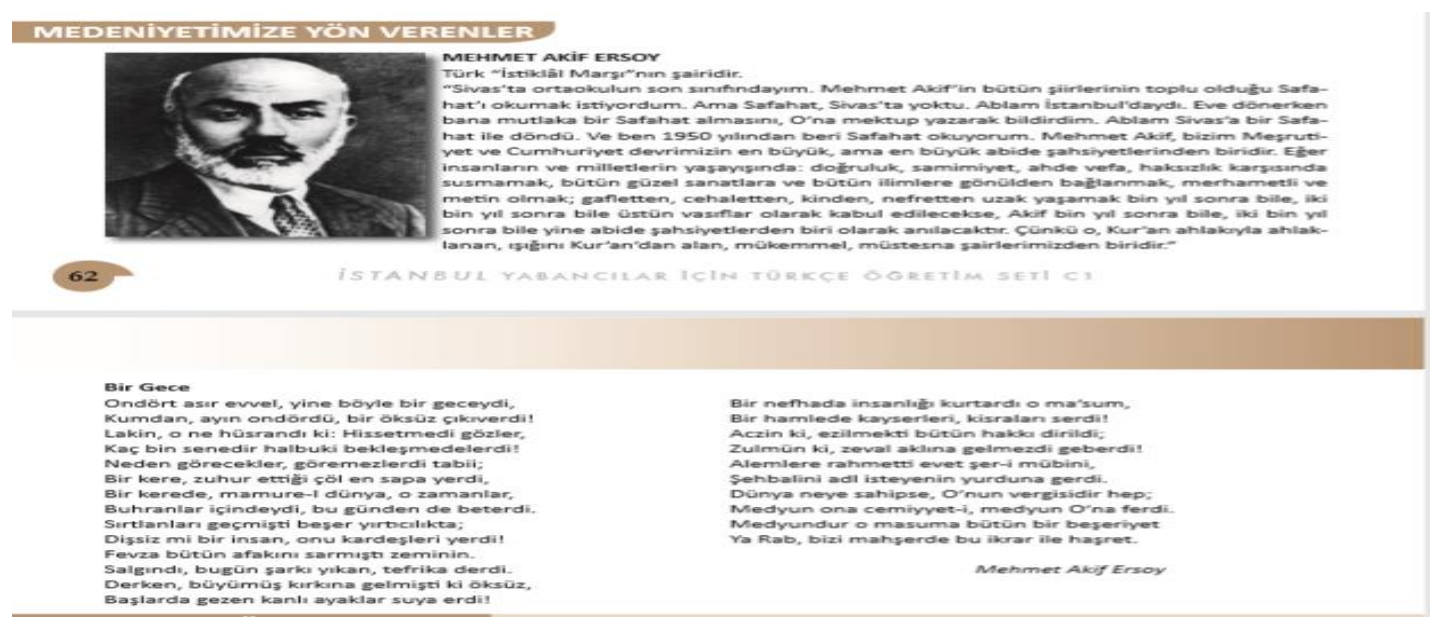

Görsel 3: Şahsiyetlerin metin bağlamında işlenişine dair örnek metin

Kaynak: İstanbul C1 ders kitab1, s. 62

Yukarıdaki görsele bakıldığında metnin doğrudan Mehmet Akif Ersoy üzerine kurulduğu görülmektedir. Burada da yukarıdaki iki kategoriden farklı olarak şahsiyeti doğrudan tanıtmanın amaçlandığı anlaşılmaktadır. Bu bağlamda ilgili şahsiyetin önce hayatı, daha sonra kişisel özellikleri verilmiş ve bir şirii üzerinden sanatçı kimliği ön plana çıkarılmıştır.

İlgili kodlamalar yukarıda verilen örneklerdeki gibi yapıldıktan sonra kodlayıcılar arasındaki güvenirlik her seviyede ders kitabında tespit edilen şahsiyetler bağlamında ayrı ayrı yapılmıştır. Bu çerçevede her iki kodlayıcı tarafından A1 seviyesinden C1 seviyesine kadar bütün ders kitaplarındaki şahsiyetlerin belirlenen 3 kriterden hangisine girdiğine yönelik karşılaştırmalar yapılmış ve her iki kodlayıcı tarafindan farklı kriterde kodlananlar üzerinden Miles ve Huberman'ın (1994) formülü (Güvenirlik = görüş birliği / görüş birliğ $\mathrm{i}+$ görüş ayrılığ $\mathrm{X} 100$ ) kullanılarak hesaplanmıştır. İlgili hesaplamalar sonucu İstanbul setinde tespit edilen 97 şahsiyet üzerinden güvenirlik 89/97x100=\%91; Yedi İklim setinde ise tespit edilen 164 şahsiyet üzerinden güvenirlik 146/164x100=\%89 olarak hesaplanmıştır. Bu sonuçlardan hareketle kodlayıcılar arası güvenirlik hesaplarının \%80'in üzerinde çıkması, araştırma için güvenilir kabul edilmektedir (Miles ve Huberman, 1994: 64). Tüm bu işlemlerden sonra ilgili veriler tablolara nicelleştirilerek yerleştirilmiş ve döküman inceleme sürecinin üçüncü aşaması olan yorumlama bağlamında ilgili tablolar araştırmada kullanılan settler bağlamında hem kendi içinde hem de karşılaştırmalı olarak yorumlanmıştır.

\section{Çalışma Materyalleri}

Bowen (2009:38) doküman inceleme tekniğinin kullanılacağı araştırmalarda "araştırmacı / analistin, her belgenin orijinal amacı, üretildiği bağlam ve hedeflenen kitle dikkate alınarak sadece varlığını ve erişilebilirliğini değil, belirli belgelerin gerçekliğini ve kullanışlılığını da belirlemesi gerektiğini ve belgelerde yer alan verilerin öznel yorumlayıcısı olarak, araştırmacı analiz sürecini 
olabildiğince titiz ve şeffaf hâle getirmeli" husunu vurgular. Bu bağlamda ilgili araştırma çerçevesinde asıl amacı yabancı dil olarak Türkçe öğrenenlere Türkçe öğretmek için hazırlanan A1, A2, B1, B2, C1 ve C2 (C+) düzeyindeki Yedi İklim Türkçe Ders Kitab1 ve İstanbul Yabancılar İçin Türkçe ders kitapları çalışma materyali olarak belirlenmiş ve nesnel bir yaklaşımla tespit edilen veriler okuyuculara bir bakış açısı sunmak amacıyla yorumlanmıştır.

\section{Bulgular}

Araştırmada elde edilen bulgular gerekli analizler ve betimlemeler yapılarak tablolar hâlinde sunulmuștur.

\section{Birinci Alta Amaca İlişkin Bulgular:}

Aşağıdaki tabloda İstanbul ve Yedi İklim setlerinde yer verilen şahsiyetlerin listesi verilmiştir.

Tablo 1: İstanbul ve Yedi İklim Ders Kitaplarında Bulunan Şahsiyetlerin Listesi

\begin{tabular}{|c|c|c|c|c|c|c|c|}
\hline 1 & Abdullah Gül & 50 & Erol Günaydın & 98 & Kül Tigin & 146 & Sadık Şendil \\
\hline 2 & $\begin{array}{l}\text { Abdulrahim } \\
\text { Karakoç }\end{array}$ & 51 & Ersin Düzen & 99 & $\begin{array}{l}\text { Kütüphaneci Mustafa } \\
\text { Bey }\end{array}$ & 147 & Saffet Ulusoy \\
\hline 3 & II. Abdülhamit & 52 & Ertem Eğilmez & 100 & Latife Hanım & 148 & Sakıp Sabancı \\
\hline 4 & Adile Naşit & 53 & Eşref Armağan & 101 & Lokman Hekim & 149 & Selah Cerrar \\
\hline 5 & Agah Efendi & 54 & Ethem Çalışkan & 102 & $\begin{array}{l}\text { Matrakçı Nasuh } \\
\text { Efendi }\end{array}$ & 150 & $\begin{array}{l}\text { Selen Işık } \\
\text { (Pucca) }\end{array}$ \\
\hline 6 & $\begin{array}{l}\text { Ahmet Hamdi } \\
\text { Tanpınar }\end{array}$ & 55 & Evliya Çelebi & 103 & Marko Paşa & 151 & 2. Selim \\
\hline 7 & Ahmet Haşim & 56 & Fatih Akın & 104 & Mehmet Akif Ersoy & 152 & Serdar Akar \\
\hline 8 & Ahmet N. Zorlu & 57 & Fatih (Sultan Mehmet) & 105 & Mehmet Ali Birand & 153 & Servet Tazegül \\
\hline 9 & Ak Şemseddin & 58 & Fatma Aliye Hanım & 106 & Mehmet (Okur) & 154 & Setenay Alpsoy \\
\hline 10 & Aleaddin Keykubat & 59 & Feridüddin Attar & 107 & Mehmet Öz & 155 & Sezai Karakoç \\
\hline 11 & Ali Kuşçu & 60 & Feyadi & 108 & Mehmet Tatar & 156 & Sezen Aksu \\
\hline 12 & Ali Nasuh Mahruki & 61 & Fikret Mualla & 109 & Metin Erksan & 157 & Sulhi Dölek \\
\hline 13 & Ali Riza Bozkurt & 62 & Fuzuli & 110 & Mevlâna & 158 & $\begin{array}{l}\text { Sultan } \\
\text { Abdülaziz }\end{array}$ \\
\hline 14 & Arda Turan & 63 & Gül Atay & 111 & Mihrimah Sultan & 159 & Sultan Mahmut \\
\hline 15 & Asım Kibar & 64 & Güler Sabancı & 112 & Mimar Kemalettin & 160 & Sultan Veled \\
\hline 16 & Aşık Şeref Taşlıova & 65 & Gürkan Genç & 113 & Mimar Atik Sinan & 161 & Sunay Akın \\
\hline 17 & Aş1k Veysel & 66 & Hacı Bayram-1 Veli & 114 & Mimar Sinan & 162 & Şair Eşref \\
\hline 18 & Ata Demirer & 67 & Hac1 Bektaş-1 Veli & 115 & Muammer Karaca & 163 & Şair Naif \\
\hline 19 & Atıl Kutoğlu & 68 & Hafız Osman & 116 & Muhsin Ertuğrul & 164 & Şah Cihan \\
\hline 20 & Avni Tolunay & 69 & Haldun Dormen & 117 & Mustafa Kara & 165 & $\begin{array}{l}\text { Şarkışlalı } \\
\text { Serdari }\end{array}$ \\
\hline 21 & Aydın Sayılı & 70 & Hamdi Ulukaya & 118 & $\begin{array}{l}\text { Mustafa Kemal } \\
\text { Atatürk }\end{array}$ & 166 & $\begin{array}{l}\text { Şebnem } \\
\text { Dönmez }\end{array}$ \\
\hline 22 & Ayhan Işık & 71 & Hamdullah Hamdi & 119 & Mustafa Kutlu & 167 & $\begin{array}{l}\text { Şehzade } \\
\text { Mehmet }\end{array}$ \\
\hline 23 & Ayşe Kulin & 72 & Hamit Altıntop & 120 & $\begin{array}{l}\text { Mükrimin Halil } \\
\text { Yinanç }\end{array}$ & 168 & Şener Şen \\
\hline 24 & Baki & 73 & Hamza Yerlikaya & 121 & Münir Özkul & 169 & Şenol Güneş \\
\hline 25 & Barış Manço & 74 & Hasan Kaçan & 122 & Müşfik Kenter & 170 & $\begin{array}{l}\text { Şeyh } \\
\text { HamDullah }\end{array}$ \\
\hline
\end{tabular}




\begin{tabular}{|c|c|c|c|c|c|c|c|}
\hline 26 & Berk (Gürman) & 75 & Hasan Kınalı & 123 & Nabi Avcı & 171 & Şeyh Küşteri \\
\hline 27 & Berrak Tüzünataç & 76 & Hayati Develi & 124 & Namdar Nabi Karatay & 172 & Şinasi \\
\hline 28 & 2. Beyazit & 77 & Hazerfen Ahmet Çelebi & 125 & Nasrettin Hoca & 173 & Şükran Güngör \\
\hline 29 & Bilge Kağan & 78 & Hizır Bey & 126 & Nazım Hikmet & 174 & Şükrü Andaç \\
\hline 30 & Cahit Arf & 79 & Hidayet (Türkoğlu) & 127 & Nazmiye Muslu & 175 & Tahsin Yücel \\
\hline 31 & Cahit Şimşek & 80 & Hilmi Ziya Ülken & 128 & Necati Cumalı & 176 & Tapduk Emre \\
\hline 32 & Can Yücel & 81 & Hilmi Yavuz & 129 & Necip Fazıl Kısakürek & 177 & Tarık Akan \\
\hline 33 & Cem Sultan & 82 & Hulusi Behçet & 130 & Nef'i & 178 & $\begin{array}{l}\text { Tarık Dursun } \\
\text { Kakınç }\end{array}$ \\
\hline 34 & Cem Yilmaz & 83 & Hülya Koçyiğit & 131 & Nejat Eczacıbaşı & 179 & Tarkan \\
\hline 35 & Cemal Reşit Rey & 84 & Hürrem Sultan & 132 & Neşet Ertaş & 180 & $\begin{array}{l}\text { Tasasız Raziye } \\
\text { Sultan }\end{array}$ \\
\hline 36 & Cemal Süreya & 85 & Hüsnü Özyeğin & 133 & Neyzen Tevfik & 181 & Tevfik Fiket \\
\hline 37 & Cemil Meriç & 86 & Itri & 134 & Nihat Kahveci & 182 & Tonyukuk \\
\hline 38 & Cengiz Aytmatov & 87 & İbrahim Kutluay & 135 & Oğuz Atay & 183 & Tuncay Şanl1 \\
\hline 39 & Cengiz Dağc1 & 88 & İbrahim Tatlıses & 136 & Okan Bayülgen & 184 & Turan Oflazoğlu \\
\hline 40 & Çağan Irmak & 89 & İdil Biret & 137 & Oktay Akbal & 185 & Türkan Şoray \\
\hline 41 & Çetin Altan & 90 & İshak Alaton & 138 & Orhan Aksoy & 186 & Uluğ Bey \\
\hline 42 & Dede Efendi & 91 & Kadir İnanır & 139 & Orhan Bey & 187 & Yaşar Kemal \\
\hline 43 & Dede Korkut & 92 & $\begin{array}{l}\text { Kanuni Sultan } \\
\text { Süleyman }\end{array}$ & 140 & Orhan Pamuk & 188 & $\begin{array}{l}\text { Yavuz Sultan } \\
\text { Selim }\end{array}$ \\
\hline 44 & Deliktaşl1 Ruhsati & 93 & Kaşgarlı Mahmut & 141 & Öykü Gürman & 189 & Yavuz Turgul \\
\hline 45 & Ebru Gündeş & 94 & Kemal Sunal & 142 & Piraye & 190 & Y1ldız Kenter \\
\hline 46 & Efkan Çalış & 95 & Kenan Sofuoğlu & 143 & Rahmi Koç & 191 & Yunus Emre \\
\hline 47 & Emine Işınsu & 96 & Kıraç & 144 & Reşat Nuri Güntekin & 192 & Zeki Alasya \\
\hline 48 & (Ercişli) Emrah & 97 & Koray Löker & 145 & Sabri Esat Siyavuşgil & 193 & Zeki Alpan \\
\hline
\end{tabular}

Tablo 1'e bakıldığında her iki setin bütün seviyelerinin toplamında 193 şahsiyete yer verildiği görülmektedir. Ayrıca setlerde yer verilen şahsiyetlerin 174'ünün erkek 23'ünün ise kadın olduğu ve cinsiyet bağlamlı dağılımda eşitlik olmadığı görülmektedir. İlgili şahsiyetlerin tanındıkları alanlara göre kategorize edilmiş biçimi aşağıdaki gibidir:

\section{İkinci Alta Amaca İlişkin Bulgular:}

İstanbul ve Yedi İklim setlerinde verilen şahsiyetlerin tanındıkları alanlara göre dağılımlarını gösteren tablo aşağıdaki gibidir: 
Tablo 2: Ders Kitaplarında Bulunan Şahsiyetlerin Tanındıkları Alanlara Göre Dağılımı

Kitaplardaki Ünlü Şahsiyetlerin Meslek Grupları

Yazar, şair, senarist $\quad$ Ayşe Kulin, Ahmet Hamdi Tanpınar, Baki ,Can Yücel, Cemil Meriç, Cengiz Aytmatov, Cengiz Dağcı, Deliktaşlı Ruhsati, Ercişli Emrah, Fatma Aliye Hanım, Feridüddin Attar, Hilmi Ziya Ülken, Hilmi Yavuz, Itri, Mehmet Akif Ersoy, Mustafa Kutlu, Nazım Hikmet, Namdar Nabi Karatay, Nazım Hikmet, Necati Cumalı, Necip Fazıl, Nefi, Neyzen Tevfik, Oktay Akbal, Oğuz Atay, Orhan Pamuk, Sadık Şendil, Sabri Esat Siyavuşgil, Sezai Karakoç, Sulhi Dölek, Sunay Akın, Şair Eşref, Şair Naif, Şarkışlalı Serdar, Şinasi, Reşat Nuri Güntekin, Tevfik Fikret, Turhan Oflazoğlu, Yaşar Kemal.

Sporcu (Dağcı, futbolcu, Ali Nasuh Mahruki, Arda Turan, Hamit Altıntop, Efkan Çalış, Erden Eruç, Gürkan Genç, matrakçı, bisiklet sporcusu, güreşçi, atlet, Hamit Altıntop, Hamza Yerlikaya, Hasan Kınalı, Hidayet Türkoğlu, İbrahim Kutluay, Nazmiye Muslu, Nihat Kahveci Mehmet Okur, Mehmet Tatar, Şenol Güneş, Servet halterci, basketbolcu, antrenör, tekvandocu, motosiklet yarışçıs1)

Müzisyen (ses sanatçısı, Aşık Veysel, Aşık Şeref Taşlıva, İdil Biret, Barış Manço, Berk (Gürman), Ebru Gündeş, piyanist)

Bilim İnsanı İbrahim Tatlıses, Neşet Ertaş, Öykü (Gürman), Sezen Aksu, Kıraç, Tarkan.

\begin{tabular}{ll} 
& Aydın Sayılı, Cahit Arf, Hayati develi, Hulusi Behçet, Hilmi Ziya Ülken, Mustafa Ziya \\
& Halil Yınanç, Mehmet Öz. \\
\hline Ressam & Eşref Armağan, Fikret Mualla, Setenay Alpsoy.
\end{tabular}

Oyuncu, tiyatrocu, Ayhan Işık, Adile Naşit, Berrak Tüzünataç, Erol Günaydın, Hasan Kaçan, Kadir İnanır, komedyen Kemal Sunal, Müşfik Kenter, Münir Özkul, Şebnem Dönmez, Şener Şen, Şükran Güngör, Tarık Akan, Zeki Alasya, Zeki Alpan, Türkan Şoray, Zeki Alpan, Yıldız Kenter. Okan Bayülgen, Ata Demirer, Cem Y1lmaz.

\begin{tabular}{ll}
\hline Yönetmen & $\begin{array}{l}\text { Çağan Irmak, Ertem Eğilmez, Fatih Akın, Metin Erksan, Orhan Aksoy, Serdar Akar, } \\
\text { Yavuz Turgul. }\end{array}$ \\
\hline Gazeteci-televizyoncu & Çetin Altan, Mehmet Ali Birand, Ersin Düzen, Şükrü Andaç, \\
\hline İş insanı & Ahmet N. Zorlu, Asım Kibar, Güler Sabanc, Hamdi Ulukaya, Hüsnü Özyeğin, İshak \\
& Alaton, Nejat Eczacıbaşı, Rahmi Koç, Saffet Ulusoy, Sakıp Sabanci. \\
\hline Siyasetçi & Abddullah Gül, Avni Tolunay, Nabi Avcı. \\
\hline Tarihi Şahsiyet & Mustafa Kemal Atatürk, Ak Şemseddin, Ali Kuşçu, 2. Beyazıd, Aleaddin Keykubat, Bilge \\
(Hükümdarlar ve ailesi, & Kağan, Cem Sultan, Dede Efendi, Dede Korkut, Evliya Çelebi, Fatih Sultan Mehmet, Haç \\
bilim insanı, düşünür, & Bayram-I Veli, Hacı Bektaş-I Veli, Hızır Bey, Kül Tigin, Tonyukuk Dede Korkut, Hürrem \\
müzisyen, hekim, mimar, & Sultan, Latife Hanım, Lokman Hekim, Kaşgarlı Mahmut, Nasreddin Hoca, Mevlana, \\
astronom) & Evliya Çelebi, Hazarfen Ahmet Çelebi, Ak Şemseddin, Matrakçı Nasuh Efendi, Marko \\
& Paşa, Mevlana, Mihrimah Sultan, Mimar Kemalettin, Mimar Atik Sinan, Mimar Sinan, \\
& Nasreddin Hoca, Orhan Bey, Piraye, 2. Selim, Sultan Abdülaziz, Sultan Mahmud, Sultan \\
& Veled, Şah Cihan, Şehzade Mahmud, Tapduk Emre, Tasasız Raziye, Uluğ Bey, Yavuz \\
& Sultan Selim, Yunus Emre, Lokman Hekim. \\
\hline Hattat & Hafiz Osman, Şeyh Hamdullah. \\
\hline Karagöz Ustası & Şeyh Küşteri. \\
\hline Kütüphaneci & Mustafa Bey. \\
\hline Modacı & Âtıl Kutoğlu. \\
\hline
\end{tabular}

Tablo 2'ye bakıldığında her iki ders kitabının bütün seviyelerinin taranması sonucu tespit edilen şahsiyetler 15 farklı kategoride (yazar, şair, senarist, sporcu, müzisyen, bilim insanı, ressam, yönetmen, gazeteci-televizyoncu, iş insanı, tarihi şahsiyet, hattat, karagöz ustası, kütüphaneci, modacı) toplanmıştır. Bu çerçeveden bakıldığında şahsiyetlerin tanınırlık alanlarına göre dağılımlarında bir eşitliğin veya sistematiğin olmadığg söylenebilir.

\section{Üçüncü Alt Amaca İlişkin Bulgular:}

Türkçe öğretiminde kullanılan ders kitaplarındaki şahsiyetlerin veriliş şekli, "sadece isim olarak yer verilenler", "metinde özelliklerine yer verilenler" ve "metin bağlamında işlenmiş" olmak üzere 3 ayrı başlık altında incelenmiştir. Bu bağlamda ilgili şahsiyetlere ders kitaplarında veriliş şekli ve oranına ilişkin bulgular aşağıdaki gibidir. 
Tablo 3: Şahsiyetlerin Ders Kitaplarında Veriliş Şekli ve Oranı

Şahsiyetlerin veriliş şekli ve oranları

\begin{tabular}{|c|c|c|c|c|c|c|c|c|}
\hline \multirow{3}{*}{ 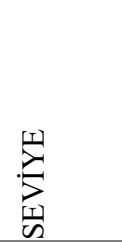 } & \multicolumn{8}{|c|}{ Şahsiyetlerin veriliş şekli ve oranları } \\
\hline & \multicolumn{4}{|c|}{ İstanbul Yabancılar İçin Türkçe Seti } & \multicolumn{4}{|c|}{ Yedi İklim Türkçe Seti } \\
\hline & $\begin{array}{l}\text { İsim } \\
\text { olarak } \\
\text { yer } \\
\text { verilmiş }\end{array}$ & $\begin{array}{l}\text { Metinde } \\
\text { özelliklerine } \\
\text { yer verilmiş }\end{array}$ & $\begin{array}{l}\text { Metin } \\
\text { bağlamında } \\
\text { işlenmiş }\end{array}$ & Toplam & $\begin{array}{l}\text { İsim } \\
\text { olarak } \\
\text { yer } \\
\text { verilmiş }\end{array}$ & $\begin{array}{l}\text { Metinde } \\
\text { özelliklerine } \\
\text { yer verilmiş }\end{array}$ & $\begin{array}{l}\text { Metin } \\
\text { bağlamında } \\
\text { işlenmiş }\end{array}$ & Toplam \\
\hline A1 & 0 & 1 & 0 & 1 & 5 & 0 & 3 & 8 \\
\hline $\mathrm{A} 2$ & 6 & 4 & 3 & 7 & 9 & 9 & 17 & 35 \\
\hline $\mathrm{B} 1$ & 9 & 3 & 1 & 13 & 8 & 2 & 12 & 22 \\
\hline B2 & 5 & 3 & 1 & 9 & 5 & 7 & 7 & 19 \\
\hline $\mathrm{C} 1$ & 19 & 6 & 7 & 32 & 20 & 13 & 9 & 42 \\
\hline $\mathrm{C} 2$ & 27 & 0 & 8 & 35 & 20 & 7 & 11 & 38 \\
\hline Toplam & 66 & 17 & 20 & 97 & 67 & 38 & 59 & 164 \\
\hline$\%$ & 64,02 & 16,49 & 19,4 & 100 & 40,85 & 23,17 & 35,97 & 100 \\
\hline
\end{tabular}

Tablo 3'e bakıldığında İstanbul setinde toplam 97, Yedi İklim setinde ise 164 şahsiyete yer verildiği görülmektedir. İstanbul setinde yer alan şahsiyetlerin 66'sına $(\% 64,02)$, Yedi İklim setinde ise 67'sine $(\% 40,85)$, isim olarak yer verildiği görülmektedir. Metinde özellikleri verilen şahsiyetlerin oranına bakıldığında ise İstanbul'da $17(\% 16,49)$, Yedi İklim'de ise $38(\% 23,17)$, şahsiyetin özelliklerine yer verildiği dikkat çekmektedir. Metin bağlamında işlenmiş olan şahsiyetlerin verilme oranına bakıldığında ise İstanbul setinde $20(\% 19,4)$, Yedi İklim setinde ise 59 $(\% 35,97)$ şahsiyete yer verildiği görülmektedir.

Her iki kitap setine seviye bazlı bakıldığında temel seviyede (A1-A2) İstanbul setinde 8, Yedi İklim'de 43, orta düzeyde (B1-B2) İstanbul setinde 22, Yedi İklim'de 41, ileri seviyede (C1C2- C+) ise İstanbul setinde 46, Yedi İklim'de 40 şahsiyete yer verildiği tespit edilmiştir. Bu bağlamda, Yedi İklim setinde şahsiyetlere her üç kategoride de (sadece isim olarak yer verilenler, "metinde özelliklerine yer verilenler ve metin bağlamında işlenmiş) daha fazla yer verildiği görülmektedir. İlgili şahsiyetlerin seviyelere göre ders kitaplarında veriliş durumlarını gösteren detaylı bilgiler ise aşağıdaki gibidir:

\section{Al seviyesindeki ders kitaplarında şahsiyetlerin verilişş şekli ve oranına ait bulgular}

Her iki setin ders kitabındaki şahsiyetlerin veriliş şekilleri ve oranlarına ait bulgulara bakıldığında "sadece isim olarak yer verilenler", "metinde özelliklerine yer verilenler" ve "metin bağlamında işlenmiş" kategorilerine ek olarak hangi beceri alanında verildiği bağlamında da tespitler yapılmıştır. Bu çerçevede ilgili bulgular aşağıdaki tablo 4 ve 5 'teki gibidir:

Tablo 4: Şahsiyetlerin, İstanbul A1 Ders Kitabında Veriliş Şekli ve Oranı

\begin{tabular}{|c|c|c|c|c|c|}
\hline Kitabin Adı: & \multicolumn{5}{|c|}{ İstanbul Yabancılar İçin A1 Türkçe Ders Kitabı } \\
\hline \multirow[t]{4}{*}{ Şahsiyet } & \multirow{2}{*}{\multicolumn{3}{|c|}{ Metinde Yer Veriliş Şekli }} & \multirow{2}{*}{\multicolumn{2}{|c|}{$\begin{array}{l}\text { Metnin İlgili olduğu } \\
\text { Beceri }\end{array}$}} \\
\hline & & & & & \\
\hline & $\begin{array}{l}\text { İsim olarak yer } \\
\text { verilmiş }\end{array}$ & $\begin{array}{l}\text { Metinde özelliklerine yer } \\
\text { verilmiş }\end{array}$ & $\begin{array}{l}\text { Metin bağlamında } \\
\text { işlenmiş }\end{array}$ & Okuma & Dinleme \\
\hline & \multicolumn{5}{|c|}{ Sayfa numaras1 } \\
\hline $\begin{array}{ll}1 & \text { İbrahim } \\
& \text { Kutluay }\end{array}$ & & 11 & & 11 & \\
\hline
\end{tabular}

Tablo 4'e bakıldığgnda ilgili ders kitabında sadece "İbrahim Kutluay"a yer verildiği, veriliş şekli olarak kitabın 11. sayfasında okuma becerisi içinde metinde özelliklerinin anlatıldığ 1 tespit edilmiştir. 
Tablo 5: Şahsiyetlerin, Yedi İklim A1 Ders Kitabında Veriliş Şekli ve Oranı

Kitabın Adı:

Şahsiyet Yedi İklim Türkçe A1 Ders Kitabı

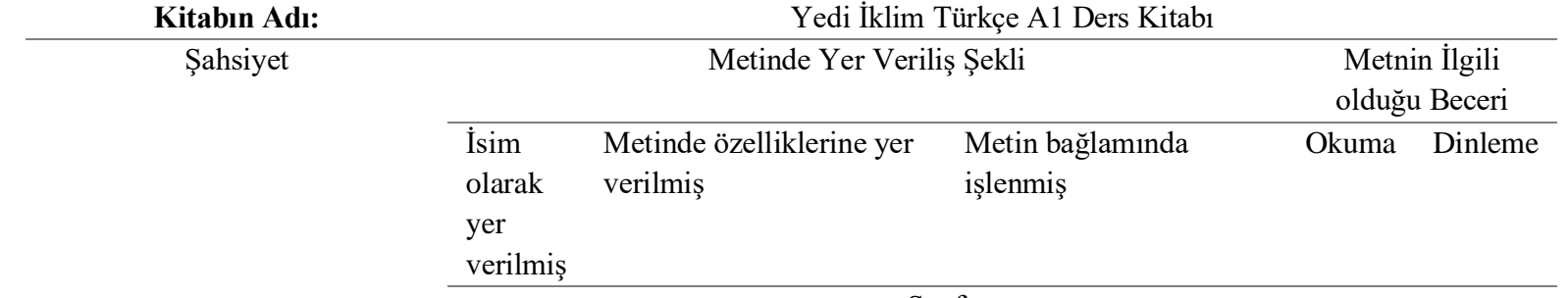

Sayfa numaras1

\begin{tabular}{|c|c|c|c|c|c|}
\hline 1 & Mehmet (Okur) & 46 & & 46 & \\
\hline 2 & Hidayet (Türkoğlu) & 46 & & 46 & \\
\hline 3 & Hacı Bayram-1 Veli & 94 & 91 & 94 & 91 \\
\hline 4 & Fatih Sultan Mehmet & 91 & & & 91 \\
\hline 5 & Ak Şemseddin & 91 & & & 91 \\
\hline 6 & Eşref Armağan & & 111 & 111 & \\
\hline 7 & Kenan Sofuoğlu & & 126 & 126 & \\
\hline
\end{tabular}

Tablo 5'e bakıldığında ilgili kitapta $7(\% 11,48)$ şahsiyete yer verildiği (Mehmet Okur, Hidayet Türkoğlu, Hacı Bayram-1 Veli, Fatih Sultan Mehmet, Ak Şemseddin, Eşref Armağan ve Kenan Sofuoğlu) görülmektedir. Bu kişilerden 5'ine sadece isim olarak yer verilirken 3'ü ise metin bağlamında işlenmiştir. Ayrıca beceri bağlamında da bakıldığında ilgili kişilerden metnin doğrudan kendisi ile ilgili olduğu 3 kişi (Hacı Bayram-1 Veli, Eşref Armağan ve Kenan Sofuoğlu) ve isim olarak verilen 2 şahıs (Mehmet Okur, Hidayet Türkoğlu) okuma becerisi kapsamında, diğerleri ise dinleme becerisi kapsamında verildiği görülmektedir. Ayrıca Hacı Bayram-1 Veli’ye hem okuma hem de dinleme becerisi bağlamında kitabın 94 ve 91. sayfalarında 2 kez yer verilmiştir.

Yukarıdaki bilgiler kapsamında tablo 4 ve 5 birlikte yorumlandığında Yedi İklim Türkçe A1 Ders Kitabı'nda verilen şahsiyetlerin hem veriliş oranı hem de veriliş şekli olarak İstanbul kitabından daha kapsamlı olduğu görülmektedir.

\section{A2 Seviyesindeki Ders Kitaplarında Şahsiyetlerin Veriliş Şekli ve Oranına Ait Bulgular}

İstanbul ve Yedi İklim kitabının A2 seviyesi ders kitaplarındaki şahsiyetlerin veriliş şekli ve oranlarına ait bulgular Tablo 6 ve 7'deki gibidir:

Tablo 6: Şahsiyetlerin, İstanbul A2 Ders Kitabında Veriliş Şekli ve Oranı

\begin{tabular}{|c|c|c|c|c|c|c|c|}
\hline & \multirow{4}{*}{$\begin{array}{c}\text { Kitabın Adı: } \\
\text { Şahsiyet }\end{array}$} & \multicolumn{6}{|c|}{ İstanbul Yabancılar İçin A2 Türkçe Ders Kitab1 } \\
\hline & & \multicolumn{3}{|c|}{ Metinde Yer Veriliş Şekli } & \multicolumn{3}{|c|}{ Metnin İlgili Olduğu Beceri } \\
\hline & & $\begin{array}{l}\text { İsim } \\
\text { olarak } \\
\text { yer } \\
\text { verilmiş }\end{array}$ & $\begin{array}{l}\text { Metinde } \\
\text { özelliklerine } \\
\text { yer verilmiş }\end{array}$ & $\begin{array}{l}\text { Metin } \\
\text { bağlamında } \\
\text { işlenmiş }\end{array}$ & Okuma & Dinleme & Konuşma \\
\hline & & \multicolumn{6}{|c|}{ Sayfa numaras1 } \\
\hline 1 & Mehmet Öz & 10 & & & 10 & & \\
\hline 2 & Orhan Pamuk & 24,75 & & 26 & 24,75 & 26 & \\
\hline 3 & Fatih Sultan Mehmet & 26 & & 26 & & 26 & \\
\hline 4 & Hezarfen Ahmet Çelebi & & & 34 & 34 & 55 & \\
\hline 5 & Ebru Gündeş & & 55 & & & 55 & \\
\hline 6 & İbrahim Tatlises & & 55 & & & 55 & \\
\hline 7 & Tarık Akan & & 55 & & & 55 & \\
\hline 8 & Tarkan & & 55 & & & 55 & \\
\hline 9 & Nasreddin Hoca & 60 & & & 75 & & 60 \\
\hline 10 & Yaşar Kemal & 75 & & & & & \\
\hline
\end{tabular}


Tablo 6'ya bakıldığında ilgili kitapta $10(\% 9,07)$ şahsiyete yer verildiği (Mehmet Öz, Orhan Pamuk, Fatih Sultan Mehmet, Hazarfen Ahmet Çelebi, Ebru Gündeş, İbrahim Tatlıses, Tarık Akan, Tarkan, Nasreddin Hoca ve Yaşar Kemal) görülmektedir. Bu şahsiyetlerin 6'sına isim olarak yer verilirken 4'ünün metin arac1lığ i ile özelliklerine yer verildiği, 3'ünün ise doğrudan metin kendisi ile ilgili olduğu tespit edilmiştir. Aynı zamanda Orhan Pamuk ve Fatih Sultan Mehmet'e hem isim olarak hem de doğrudan kendileriyle ilgili metin aracılığı ile yer verilmiştir. Beceri bağlamında bakıldığında ise ders kitabının 55. sayfasında da görüldüğü üzere metinde özelliklerine yer verilenlerin tamamı ile sadece ismi geçen 2 şahsiyet dinleme becerisi aracıllı̆̆ ile verilmiştir. Nasreddin hoca konuşma becerisi aracılığ 1 ile verilmiştir. Bunlara ek olarak Orhan Pamuk ve Hazarfen Ahmet Çelebi okuma becerisi aracılığ ile verilmekle birlikte metin içerisinde özelliklerine yer verilenler kategorisinde tespit edilmiştir.

Yedi İklim A2 Türkçe Ders Kitabında şahsiyetlerin veriliş şekli ve oranına ait bulgular tablo 7'deki gibidir:

Tablo 7: Şahsiyetlerin, Yedi İklim A2 Ders Kitabında Veriliş Şekli ve Oranı

\begin{tabular}{|c|c|c|c|c|c|c|}
\hline \multirow{4}{*}{\multicolumn{2}{|c|}{\begin{tabular}{|c|} 
Kitabın Adı: \\
Şahsiyet \\
\end{tabular}}} & \multicolumn{5}{|c|}{ Yedi İklim Türkçe A2 Ders Kitabı } \\
\hline & & \multicolumn{3}{|c|}{ Metinde Yer Veriliş Şekli } & \multicolumn{2}{|c|}{$\begin{array}{l}\text { Metnin İlgili } \\
\text { olduğu Beceri }\end{array}$} \\
\hline & & $\begin{array}{l}\text { İsim olarak yer } \\
\text { verilmiş }\end{array}$ & $\begin{array}{l}\text { Metinde özelliklerine yer } \\
\text { verilmiş }\end{array}$ & $\begin{array}{l}\text { Metin bağlamında } \\
\text { işlenmiş }\end{array}$ & Okuma & Dinleme \\
\hline & & \multicolumn{5}{|c|}{ Sayfa numarası } \\
\hline 1 & Mustafa Kutlu & & & 14 & 14 & \\
\hline 2 & Kıraç & & & 14 & 14 & \\
\hline 3 & Arda Turan & & & 14 & 14 & \\
\hline 4 & Mimar Sinan & & & 21 & & 21 \\
\hline 5 & Nasreddin Hoca & & & 21 & & 21 \\
\hline 4 & Hac1 Bektaş-1 Veli & & & 21 & & 21 \\
\hline 6 & Yunus Emre & & & 21 & & 21 \\
\hline 7 & $\begin{array}{l}\text { Kütüphaneci } \\
\text { Mustafa Bey }\end{array}$ & & & 51 & 51 & \\
\hline 8 & Oğuz Atay & & 54 & & 54 & \\
\hline 9 & Mevlâna & & 54 & & 54 & \\
\hline 10 & Türkan Şoray & & 56 & & & 56 \\
\hline 11 & Kadir İnanır & & 56 & & & 56 \\
\hline 12 & Sadık Şendil & 59 & & & 59 & \\
\hline 13 & Orhan Aksoy & 59 & & & 59 & \\
\hline 14 & Münir Özkul & 59 & & & 59 & \\
\hline 15 & Adile Naşit & 59 & & & 59 & \\
\hline 16 & Şener Şen & 59,60 & 60 & & 59,60 & \\
\hline 17 & Yavuz Turgul & 60 & & & 60 & \\
\hline 18 & Cem Y1lmaz & 60 & & 126 & 60,126 & \\
\hline 19 & Servet Tazegül & & & 62 & 62 & \\
\hline 20 & Erden Eruç & & & 66 & 66 & \\
\hline 21 & $\begin{array}{l}\text { Atatürk (yer ismi } \\
\text { AKM) }\end{array}$ & 83 & & & & \\
\hline
\end{tabular}




\begin{tabular}{llcccc}
\hline 22 & Kemal Sunal & & 126 & 126 \\
\hline 23 & Ata Demirer & 128 & 126 & 126 & 128 \\
\hline 24 & Zeki Alasya & 128 & 126 & 126 & 128 \\
\hline 25 & Nasreddin Hoca & 127,158 & & 127,158 \\
\hline 26 & Erol Günaydın & 128 & & 128 \\
\hline 27 & Ersin Düzen & & & 139 \\
\hline 28 & Ertem Eğilmez & 139 & 161 & 161 \\
\hline 29 & Ali Nasuh Mahruki & & 162 & 168 \\
\hline 30 & Şenol Güneş & & 168 & 162 \\
\hline 31 & Barış Manço & & & 168 \\
\hline
\end{tabular}

Tablo 7'ye bakıldığında ilgili ders kitabında toplam $31(\% 18,90)$ şahsiyete yer verildiğ görülmektedir. Bunların 9'una sadece isim olarak yer verilirken, 9'unun metinde özelliklerine yer verilmiş ve 17 'sinde ise doğrudan metin kendisi ile ilgili işlenmiștir. Şener Şen, Cem Yılmaz, Ata Demirer ve Zeki Alasya ise birden fazla kategoride yer almıştır. Bu bağlamda beceri odaklı bakıldığında ise 23 şahsiyete okuma, 11'ine ise dinleme becerisi aracılığı ile verilmiştir. Ayrıca 3 kişiye ( Şenol Güneş, Zeki Alasya, Ata Demirer ) hem okuma hem dinleme becerisi aracılığ ile 2 kez yer verilmiştir.

Tablo 6 ve 7 birlikte yorumlandığında Yedi İklim Türkçe A2 Ders Kitabında verilen şahsiyetlerin hem veriliş oranı hem de veriliş şekli İstanbul Yabancılar İçin A2 Türkçe Ders Kitabından daha kapsamlı olduğu görülmektedir.

\section{B1 Seviyesindeki Ders Kitaplarında Şahsiyetlerin Veriliş Şekli ve Oranına Ait Bulgular}

İstanbul ve Yedi İklim B1 seviyesi ders kitaplarındaki şahsiyetlerin veriliş şekli ve oranına ait bulgular tablo 8 ve 9'daki gibidir:

Tablo 8: Şahsiyetlerin, İstanbul Yabancılar İçin B1 Türkçe Ders Kitabında Veriliş Şekli ve Oranı

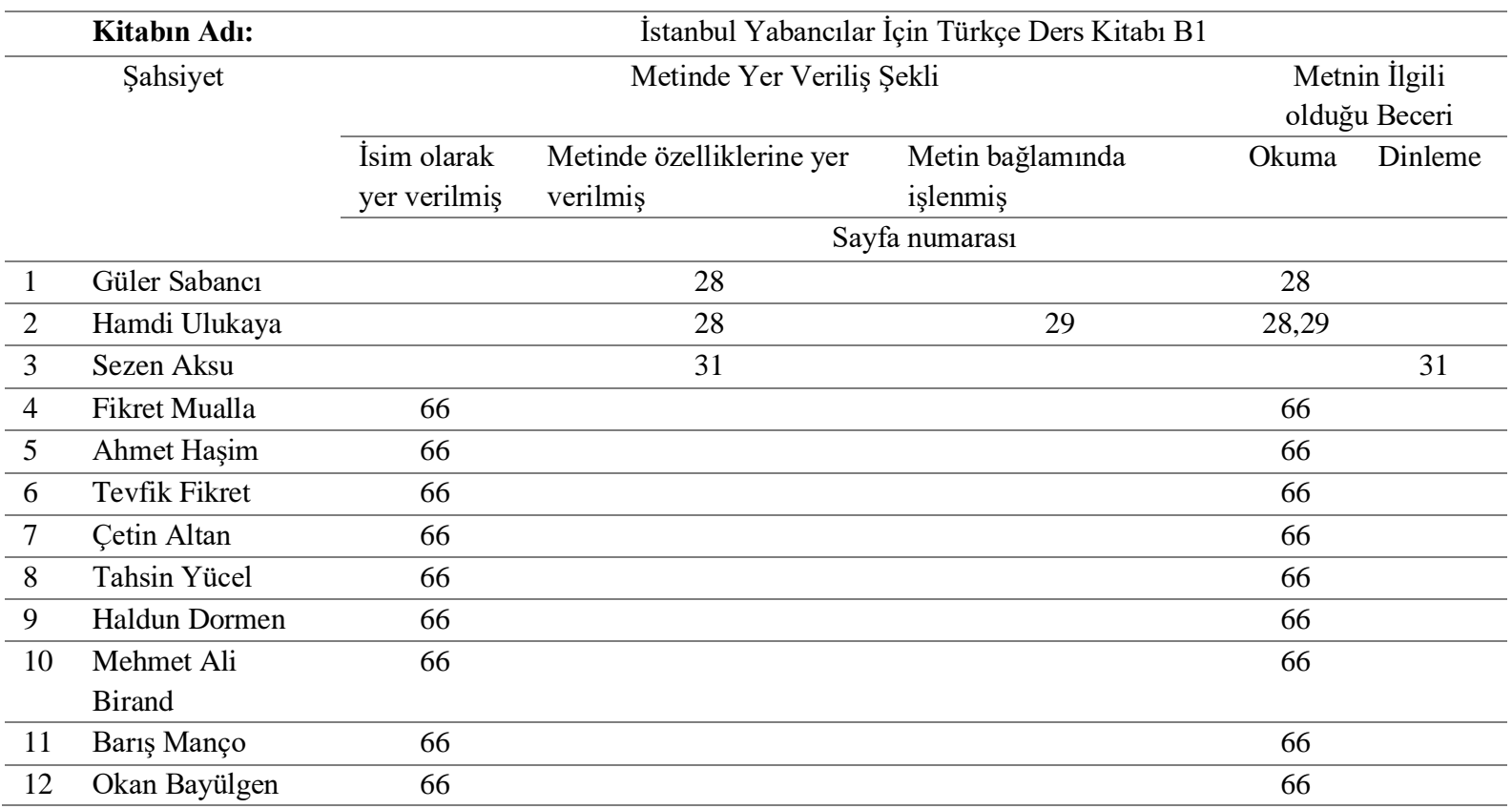


Tablo 8'e bakıldığında, İstanbul Yabancılar İçin B1 Türkçe Ders Kitabında toplam 12 $(\% 11,64)$ şahsiyete yer verildiği görülmektedir. Kitapta ilgili şahsiyetlerin 9'una kitabın 66. sayfasında isim olarak yer verilmiştir. Geriye kalanların 3'ünün (Güler Sabanc1, Hamdi Ulukaya, Sezen Aksu) metinde özelliklerine, 1'inin ise (Hamdi Ulukaya) hem özelliklerine yer verilmiş hem de metin bağlamında işlenmiştir. Beceri odaklı bakıldığında ise sadece bir şahıs (Sezen Aksu) dinleme becerisi aracılığı ile verilirken diğer bütün şahsiyetler okuma becerisi aracılığı ile verilmiştir.

Yedi İklim Türkçe B1 Ders Kitabındaki şahsiyetlerin veriliş şekli ve oranına ait bulgular tablo 9'daki gibidir:

Tablo 9: Şahsiyetlerin, Yedi İklim Türkçe B1 Ders Kitabında Veriliş Şekli ve Oranı

\begin{tabular}{|c|c|c|c|c|c|}
\hline Kitabın Adı: & \multicolumn{5}{|c|}{ Yedi İklim Türkçe B1 Ders Kitabı } \\
\hline \multirow[t]{2}{*}{ Şahsiyet } & \multicolumn{3}{|c|}{ Metinde Yer Veriliş Şekli } & $\begin{array}{r}\text { Metnin } \\
\text { B }\end{array}$ & $\begin{array}{l}\text { ili olduğu } \\
\text { eri }\end{array}$ \\
\hline & $\begin{array}{l}\text { İsim } \\
\text { olarak } \\
\text { yer } \\
\text { verilmiş }\end{array}$ & $\begin{array}{l}\text { Metinde özelliklerine yer } \\
\text { verilmiş }\end{array}$ & $\begin{array}{l}\text { Metin bağlamında } \\
\text { işlenmiş }\end{array}$ & Okuma & Dinleme \\
\hline
\end{tabular}

\begin{tabular}{|c|c|c|c|c|c|}
\hline & & \multicolumn{4}{|c|}{ Sayfa numarası } \\
\hline 1 & Mehmet Tatar & & 10 & 10 & \\
\hline 2 & Hasan Kınalı & & 10 & 10 & \\
\hline 3 & Neşet Ertaş & & 28 & 28 & \\
\hline 4 & Ethem Çalışkan & & 31 & & 31 \\
\hline 5 & Çağan Irmak & 43 & & 43 & \\
\hline 6 & Agâh Efendi & 44 & & 44 & \\
\hline 7 & Şinasi & 44 & & 44 & \\
\hline 8 & Kaşgarlı Mahmut & 57 & & 57 & \\
\hline 9 & Gül Atay & 65 & & 65 & \\
\hline 10 & Cahit Şimşek & 65 & & 65 & \\
\hline 11 & Yunus Emre & 73 & & 73 & \\
\hline 12 & Eşref Armağan & 95 & 92 & 92,95 & \\
\hline 13 & Nazmiye Muslu & & 101 & & 101 \\
\hline 14 & Âşık Veysel Şatıroğlu & & 106 & 106 & \\
\hline 15 & Reşat Nuri Güntekin & 153 & & 153 & \\
\hline 16 & (Ercişli) Emrah & 154 & & & 154 \\
\hline 17 & Mustafa Kemal Atatürk & & 156 & 156 & \\
\hline 18 & Ayşe Kulin & & 161 & 161 & \\
\hline 19 & İdil Biret & & 163 & & 163 \\
\hline 20 & Münir Özkul & & 166 & 166 & \\
\hline 21 & Adile Naşit & & 166 & 166 & \\
\hline
\end{tabular}

Tablo 9'a bakıldığında Yedi İklim Türkçe B1 Ders Kitabı'nda toplam $21(\% 12,80)$ şahsiyete yer verildiği görülmektedir. İlgili kişilerin 8'ine sadece isim olarak yer verilirken, 2'sine (Ercişli Emrah ve Eşref Armağan) metinde özellikleri anlatılarak yer verilmiş ve metin, 12 şahsiyetin doğrudan kendisi ile ilgili oluşturulmuştur. Doğrudan metin kendisi ile ilgili olan 12 kişiden 9'u okuma becerisi, 3 'ü ise dinleme becerisi aracıllı̆ 1 ile verilmiştir. Bunlara ek olarak isim olarak yer verilen 8 şahsiyetin tamamı okuma becerisi aracıllı̆ı ile verilmiştir.

Tablo 8 ve 9 birlikte analiz edildiğinde İstanbul Yabancılar İçin Türkçe B1 Ders Kitabında toplam 12, Yedi İklim Türkçe B1 Ders Kitabında ise 21 şahsiyete yer verildiği görülmektedir. Yedi İklim Türkçe B1 Ders Kitabı'nda 12, İstanbul Yabancılar İçin Türkçe Ders Kitabı B1'de ise sadece 1 şahsiyetin doğrudan metin kendileri ile ilgili oluşturulması hususu göz önünde alındığında Yedi 
İklim Türkçe B1 Ders Kitabında verilen şahsiyetlerin hem veriliş sıklığı hem de veriliş şekli olarak İstanbul Yabancılar İçin B1 Türkçe Ders Kitabından daha kapsamlı olduğu görülmektedir.

\section{B2 Seviyesindeki Ders Kitaplarında Şahsiyetlerin Veriliş Şekli ve Oranına Ait Bulgular}

B2 seviyesi ders kitaplarındaki şahsiyetlerin veriliş şekli ve oranına ait bulgular tablo 10 ve 11'deki gibidir:

Tablo 10: Şahsiyetlerin, İstanbul Yabancılar İçin B2 Türkçe Ders Kitabında Veriliş Şekli ve Oranı

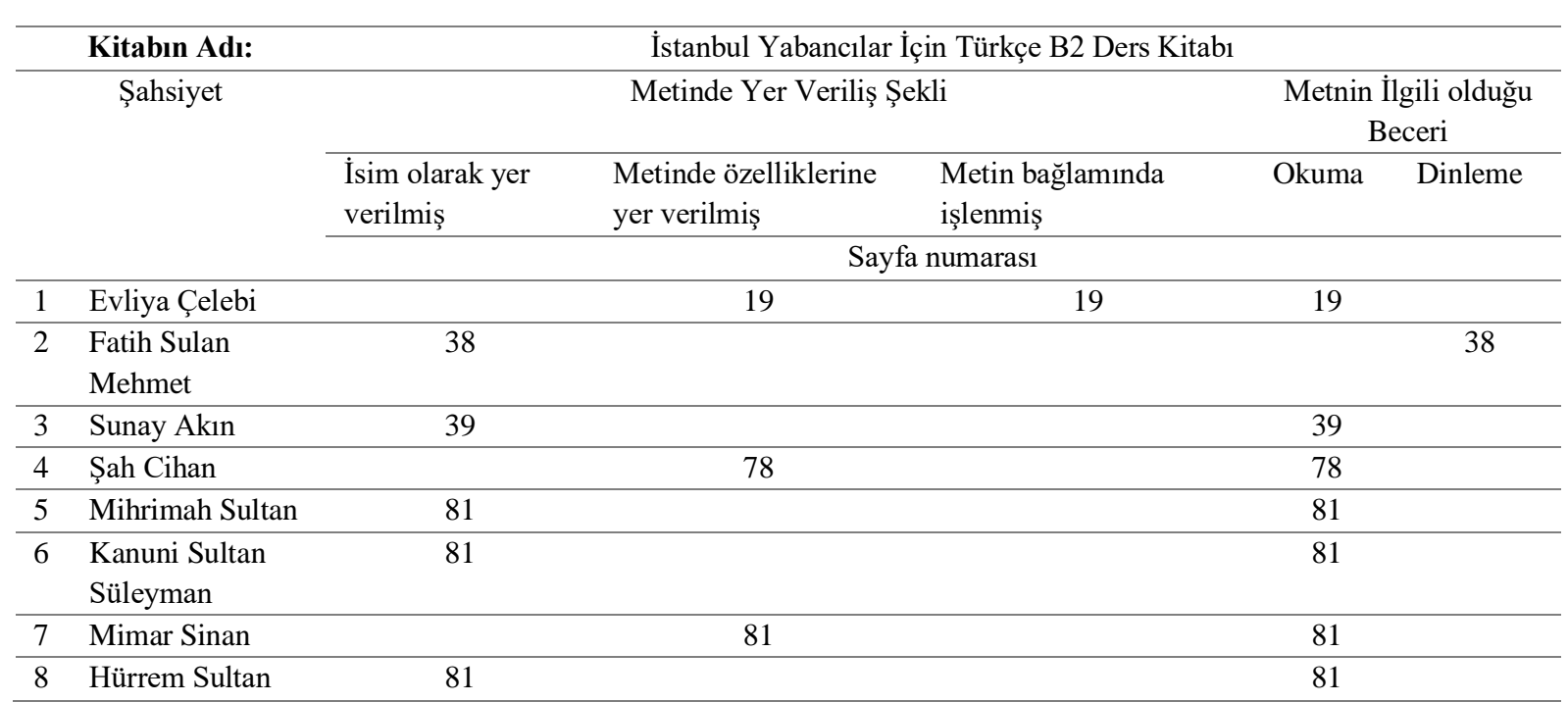

Tablo 10'a bakıldığında İstanbul Yabancılar İçin Türkçe Ders Kitabı B2'de toplam $8(\% 7,76)$ şahsiyete yer verildiği görülmektedir. Bu şahsiyetlerin 5'ine sadece isim olarak yer verilirken, 3'ünün metinde özelliklerinden bahsedilmiştir. 1'i (Evliya Çelebi) ise metin bağlamında işlenmiştir. Beceri odaklı bakıldığında, şahısların sadece 1'inin (Fatih Sultan Mehmet) dinleme diğerlerinin ise okuma becerisi aracıll̆ğ ile verildiği tespit edilmiştir.

Tablo 11: Şahsiyetlerin, Yedi İklim Türkçe B2 Ders Kitabında Veriliş Şekli ve Oranı

\begin{tabular}{|c|c|c|c|c|c|c|}
\hline & \multirow{4}{*}{$\begin{array}{c}\text { Kitabın Adı: } \\
\text { Şahsiyet }\end{array}$} & \multicolumn{5}{|c|}{ Yedi İklim Türkçe B2 Ders Kitab1 } \\
\hline & & \multicolumn{3}{|c|}{ Metinde Yer Veriliş Şekli } & \multicolumn{2}{|c|}{$\begin{array}{c}\text { Metnin İlgili olduğu } \\
\text { Beceri }\end{array}$} \\
\hline & & $\begin{array}{l}\text { İsim olarak yer } \\
\text { verilmiş }\end{array}$ & $\begin{array}{l}\text { Metinde özelliklerine yer } \\
\text { verilmiş }\end{array}$ & $\begin{array}{l}\text { Metin bağlamında } \\
\text { işlenmiş }\end{array}$ & Okuma & Dinleme \\
\hline & & \multicolumn{5}{|c|}{ Sayfa numarası } \\
\hline 1 & İshak Alaton & & 22 & & & 22 \\
\hline 2 & Asım Kibar & & 22 & & & 22 \\
\hline 3 & Rahmi Koç & & 22 & & & 22 \\
\hline 4 & Sakıp Sabancı & & 22 & & & 22 \\
\hline 5 & Ahmet N. Zorlu & & 22 & & & 22 \\
\hline 6 & Saffet Ulusoy & & 22 & & & 22 \\
\hline 7 & Mevlâna & & & 26 & 26 & \\
\hline 8 & Dede Korkut & 78 & & & 78 & \\
\hline 9 & $\begin{array}{l}\text { Fatih Sultan } \\
\text { Mehmet }\end{array}$ & 103 & & & 103 & \\
\hline
\end{tabular}




\begin{tabular}{lllll}
\hline \hline 10 & Mimar Sinan & & 113 & 113 \\
\hline 11 & $\begin{array}{l}\text { Kanuni S. } \\
\text { Süleyman }\end{array}$ & 113 & & 113 \\
\hline 12 & 2. Selim & 113 & 113 \\
\hline 13 & $\begin{array}{l}\text { Şehzade } \\
\text { Mehmet }\end{array}$ & 113 & 113 \\
\hline 14 & Türkan Şoray & 132 & 138 & 132 \\
\hline 15 & Hazerfen Ahmet & & 138 \\
& Çelebi & & 138 & 138 \\
\hline 16 & Erden Eruç & & 138 & 138 \\
\hline 17 & Gürkan Genç & 156 & 156 \\
\hline 18 & Cemil Meriç & Hüsnü Özyeğin & 156 & 156 \\
\hline 19 & & 102 & \\
\hline
\end{tabular}

Tablo 11'e bakıldığında ilgili kitabın B2 seviyesinde toplam 19 (\%11,58) şahsiyete yer verildiği tespit edilmiştir. İlgili şahsiyetlerin 5'ine sadece isim olarak yer verilirken, 7'sinin metinde özelliklerine değinilmiş ve 7'si ise metin bağlamında işlenmiştir. Bu bilgilere ek olarak beceri odaklı dağılıma bakıldığında, metinde özelliklerine yer verilen 5 şahsın (İshak Alaton, Asım Kibar, Rahmi Koç, Sakıp Sabancı ve Saffet Ulusoy) kitabın 22. sayfasında da görüleceği üzere dinleme becerisi ile geriye kalanların ise okuma becerisi ile verildiği görülmektedir.

Tablo 10 ve 11 'deki bulgular birlikte değerlendirildiğinde İstanbul kitabında toplam 8, Yedi İklim Türkçe B2 kitabında ise 19 şahsiyete yer verildiği görülmektedir. Yedi İklimde 19 şahsiyetin 7'sinde, İstanbul'da ise 8 şahsiyetten sadece 1'inde metnin doğrudan kendileri ile ilgili oluşturulmas1 hususu göz önüne alındığında Yedi İklimde verilen şahsiyetlerin hem veriliş sıklığı hem de veriliş şekli olarak İstanbul'dan çok daha kapsamlı olduğu görülmektedir.

\section{C1 Seviyesindeki Ders Kitaplarında Şahsiyetlerin Veriliş Şekli ve Oranına Ait Bulgular}

İstanbul Yabancılar İçin Türkçe Ders Kitabı B2 ve Yedi İklim Türkçe C1 Ders Kitabındaki şahsiyetlerin sıklık oranı ve veriliş şekillerine ait bulgular tablo 12 ve 13 'teki gibidir:

Tablo 12: Şahsiyetlerin, İstanbul Yabancılar İçin Türkçe C1 Ders Kitabında Veriliş Şekli ve Oran1

\begin{tabular}{|c|c|c|c|c|c|c|c|c|}
\hline & \multirow{4}{*}{$\begin{array}{c}\text { Kitabın Adı: } \\
\text { Şahsiyet }\end{array}$} & \multicolumn{7}{|c|}{ İstanbul Yabancılar İçin C1 Türkçe Ders Kitabı } \\
\hline & & \multicolumn{3}{|c|}{ Metinde Yer Veriliş Şekli } & \multicolumn{4}{|c|}{ Metnin İlgili olduğu Beceri } \\
\hline & & $\begin{array}{l}\text { İsim } \\
\text { olarak } \\
\text { yer } \\
\text { verilmiş }\end{array}$ & $\begin{array}{l}\text { Metinde } \\
\text { özelliklerine } \\
\text { yer verilmiş }\end{array}$ & $\begin{array}{l}\text { Metin } \\
\text { bağlamında } \\
\text { işlenmiş }\end{array}$ & Okuma & Dinleme & Yazma & Konuşma \\
\hline & & \multicolumn{7}{|c|}{ Sayfa numarası } \\
\hline 1 & Ali Rıza Bozkurt & 25 & & & & 25 & & \\
\hline 2 & Cengiz Dağcı & & & 27 & & & & \\
\hline 3 & Mevlâna & 36 & & & & & 36 & \\
\hline 4 & Hürrem Sultan & 37 & & & & & & 37 \\
\hline 5 & Latife Hanım & 37 & & & & & & 37 \\
\hline 6 & M.Kemal Atatürk & 37 & & & & & & 37 \\
\hline 7 & $\begin{array}{l}\text { Kanuni S. } \\
\text { Süleyman }\end{array}$ & 37 & & & & & & 37 \\
\hline 8 & Nazım Hikmet & 38 & & & & & & 37 \\
\hline 9 & Piraye & 38 & & & 38 & & & \\
\hline 10 & Cengiz Aytmatov & & & 47 & 38 & & & \\
\hline
\end{tabular}




\begin{tabular}{|c|c|c|c|c|c|}
\hline 11 & Mehmet Akif Ersoy & & & 62 & 62 \\
\hline 12 & $\begin{array}{l}\text { Fatih Sultan } \\
\text { Mehmet }\end{array}$ & & 72 & & 72 \\
\hline 13 & Hizır Bey & & 72 & & 72 \\
\hline 14 & Mimar Atik Sinan & & 72 & & 72 \\
\hline 15 & Evliya Çelebi & 72 & & & 72 \\
\hline 16 & Sezai Karakoç & & & 75 & 75 \\
\hline 17 & Marko Paşa & & & 68 & 68 \\
\hline 18 & Sultan Abdülaziz & 68 & & & 68 \\
\hline 19 & Sulhi Dölek & & 89 & & 89 \\
\hline 20 & Avni Tolunay & 95 & & & 95 \\
\hline 21 & $\begin{array}{l}\text { Necip Fazıl } \\
\text { Kısakürek }\end{array}$ & & & 96 & 96 \\
\hline 22 & Metin Erksan & & 85 & & 85 \\
\hline 23 & Fatih Akın & & 85 & & 85 \\
\hline 24 & Hülya Koçyiğit & 85 & & & 85 \\
\hline 25 & Necati Cumalı & 85 & & & 85 \\
\hline 26 & Türkan Şoray & 85 & & & 85 \\
\hline 27 & Ayhan Işık & 85 & & & 85 \\
\hline 28 & Serdar Akar & 85 & & & 85 \\
\hline 29 & Berrak Tüzünataç & 85 & & & 85 \\
\hline 30 & Şebnem Dönmez & 85 & & & 85 \\
\hline 31 & II. Abdülhamit & 111 & & & 111 \\
\hline 32 & Cemil Meriç & & & 112 & 112 \\
\hline
\end{tabular}

Tablo 12'ye bakıldığında ilgili kitabın C1 seviyesinde toplam $32(\% 31,04)$ şahsiyete yer verildiği görülmektedir. İlgili şahsiyetlerin 19'undan isim olarak bahsedilmişken, 6'sının metin içerisinde özelliklerine yer verilmiş ve 7'si ise metin bağlamında işlenmiştir. Bu bilgilere ek olarak şahsiyetlerin 21'i okuma, 4'ü dinleme, 1'i yazma ve 5'i de konuşma becerisi aracilığı ile verilmiştir.

Tablo 13: Şahsiyetlerin, Yedi İklim Türkçe C1 Ders Kitabında Veriliş Şekli ve Oranı

Kitabın Adı:

Şahsiyet
Yedi İklim Türkçe C1 Ders Kitabı

\begin{tabular}{|c|c|c|c|c|c|c|c|}
\hline \multirow{3}{*}{\multicolumn{2}{|c|}{ Şahsiyet }} & \multicolumn{3}{|c|}{ Metinde Yer Veriliş Şekli } & \multicolumn{3}{|c|}{ Metnin İlgili olduğu Beceri } \\
\hline & & $\begin{array}{l}\text { İsim } \\
\text { olarak } \\
\text { yer } \\
\text { verilmiş }\end{array}$ & $\begin{array}{l}\text { Metinde } \\
\text { özelliklerine yer } \\
\text { verilmiş }\end{array}$ & $\begin{array}{l}\text { Metin } \\
\text { bağlamında } \\
\text { işlenmiş }\end{array}$ & Okuma & Dinleme & Yazma \\
\hline & & \multicolumn{5}{|c|}{ Sayfa numarası } & \\
\hline 1 & Hamza Yerlikaya & & 14 & & & 14 & \\
\hline 2 & Arda Turan & 20 & & & & 20 & \\
\hline 3 & Hamit Altıntop & 20 & & & & 20 & \\
\hline 4 & Nihat Kahveci & 20 & & & & 20 & \\
\hline 5 & Tuncay Şanlı & 20 & & & & 20 & \\
\hline 6 & Evliya Çelebi & 32 & & & 32 & & \\
\hline 7 & $\begin{array}{l}\text { Matrakçı Nasuh } \\
\text { Efendi }\end{array}$ & 32 & & & 32 & & \\
\hline 8 & Efkan Çalış & 32 & & & 32 & & \\
\hline 9 & (Mehmet) Akif Ersoy & 56 & & & 56 & & \\
\hline 10 & Lokman Hekim & 56 & & & 56 & & \\
\hline 11 & Neyzen Tevfik & 56 & & & 56 & & \\
\hline 12 & Fatih Sultan Mehmet & 56,107 & 106 & & 56,107 & 106 & \\
\hline
\end{tabular}

Turkish Studies - Education, 15(3) 


\begin{tabular}{|c|c|c|c|c|c|c|}
\hline 13 & Yavuz Sultan Selim & 56 & 106 & & 56 & 106 \\
\hline 14 & Aşık Şeref Taşlıova & & & 61 & & 61 \\
\hline 15 & Abdulrahim Karakoç & & & 62 & 62 & \\
\hline 16 & Sezai karakoç & 64 & & & & \\
\hline 17 & Yunus Emre & & & 70,106 & 70 & \\
\hline 18 & Ton Yukuk & & 98 & & 98 & \\
\hline 19 & Kül Tigin & & 98 & & 98 & \\
\hline 20 & Bilge Kağan & & 98 & & 98 & \\
\hline 21 & 2. Beyazit & & 106 & & & 106 \\
\hline 22 & Cem Sultan & & 106 & & & 106 \\
\hline 23 & Fuzuli & 106 & & & & \\
\hline 24 & Baki & 106 & & & & \\
\hline 25 & Kaşgarlı Mahmut & & & 107 & 107 & \\
\hline 26 & Ali Kuşçu & 108 & & 107 & 107,108 & \\
\hline 27 & Uluğ Bey & 107 & & 108 & 107,108 & \\
\hline 28 & Nabi Avcı & & 128 & & 128 & \\
\hline 29 & Hayati Develi & & 128 & & 128 & \\
\hline 30 & Selah Cerrar & & 128 & & 128 & \\
\hline 31 & Hulusi Behçet & & & 129 & 129 & \\
\hline 32 & Cahit Arf & & 158 & 156 & 156,158 & \\
\hline 33 & Oğuz Atay & 156 & & & 156 & \\
\hline 34 & Hamdullah Hamdi & 168 & & & 168 & \\
\hline 35 & Sultan Mahmut & & 169 & & 169 & \\
\hline
\end{tabular}

Tablo 13'e bakıldığında ilgili ders kitabının C1 seviyesinde toplam $35(\% 21,34)$ şahsiyete yer verildiği görülmektedir. İlgili şahsiyetlerin 19'una sadece isim olarak verilmişken 13'ünün metinde özellikleri anlatılmış ve 8'i metin bağlamında işlenmiştir. Bu bilgilere ek olarak beceri odaklı analiz yapıldığında ise 24'ünün okuma, 10'unun dinleme, 1'inin ise yazma becerisi aracıllı̆ ile verildiği tespit edilmiştir. Ayrıca şahsiyetlerden Cahit Arif, Uluğ Bey, Ali Kuşçu, Fatih Sultan Mehmet ve Yavuz Sultan Selim'e 2 farklı kategoride yer verilmiştir.

Tablo 12 ve 13'e birlikte bak1ldığında A1-A2-B1 ve B2 seviyelerinin aksine C1 seviyesinde İstanbul ve Yedi İklimin yer verdiği şahsiyet sayısının birbirine oldukça yakın olduğu tespit edilmiştir. Bu bağlamda her iki kitabın da gerek şahsiyetlere yer verme sıklığı gerekse yer verme şekli göz önünde bulundurulduğunda kitapların birbirine denk olduğu söylenebilir. Buna ek olarak İstanbul'un bu seviyede şahsiyetleri sadece okuma ve dinleme değil konuşma ve yazma becerisi aracılığı ile de vermiş olması bu açıdan Yedi İklimden öne çıkarmaktadır. Bulgular

C2 ve C+ Seviyesindeki Ders Kitaplarında Şahsiyetlerin Veriliş Şekli ve Oranına Ait

İstanbul $\mathrm{C} 1+$ ve Yedi İklim C2 kitaplarındaki şahsiyetlerin veriliş şekli ve oranına ait bulgular tablo 14 ve 15 'teki gibidir: 
Tablo 14: Şahsiyetlerin, İstanbul C1+'da Veriliş Şekli ve Oranı

\begin{tabular}{|c|c|c|c|c|c|c|}
\hline Kitabın Adı: & \multicolumn{6}{|c|}{ İstanbul Yabancılar İçin C+ Türkçe Ders Kitab1 } \\
\hline \multirow[t]{3}{*}{ Şahsiyet } & \multicolumn{3}{|c|}{ Metinde Yer Veriliş Şekli } & \multicolumn{3}{|c|}{ Metnin İlgili olduğu Beceri } \\
\hline & $\begin{array}{l}\text { İsim } \\
\text { olarak } \\
\text { yer } \\
\text { verilmiş }\end{array}$ & $\begin{array}{c}\text { Metinde } \\
\text { özelliklerine yer } \\
\text { verilmiş }\end{array}$ & $\begin{array}{c}\text { Metin } \\
\text { bağlamında } \\
\text { işlenmiş }\end{array}$ & Okuma & Konuşma & Dinleme \\
\hline & & & Sayfa numar & & & \\
\hline Setenay Alpsoy & & & 122 & & & 122 \\
\hline Şeyh HamDullah & 123 & & & & & \\
\hline Hafız Osman & 123 & & & & & \\
\hline Y1ldız Kenter & & & 125 & & & 125 \\
\hline Nejat Eczacibaş1 & 126 & & & 126 & & \\
\hline Cemal Süreya & & & 127 & 127 & & \\
\hline Müşfik Kenter & 125 & & & & & 125 \\
\hline $8 \quad$ Muhsin Ertuğrul & 125 & & & & & 125 \\
\hline Şükran Güngör & 125 & & & & & 125 \\
\hline 10 Nazım Hikmet & 125 & & 156 & 156 & & 125 \\
\hline 11 Hilmi Yavuz & & & 140 & 140 & & \\
\hline 12 Nasrettin Hoca & 114 & & & 114 & & \\
\hline 13 Marko Paşa & 114 & & & 114 & & \\
\hline 14 Hasan Kaçan & & & 152 & & & \\
\hline 15 Cem Yilmaz & 154 & & & & & 154 \\
\hline 16 Cemal Reşit Rey & 168 & & & & & 168 \\
\hline 17 Zeki Alpan & 168 & & & & & 168 \\
\hline 18 Muammer Karaca & 168 & & & & & 168 \\
\hline $19 \begin{array}{l}\text { Mustafa Kemal } \\
\text { Atatürk }\end{array}$ & 160 & & & & 160 & \\
\hline $20 \quad$ Aydın Sayılı & 160 & & & & 160 & \\
\hline 21 Fatma Aliye Hanım & 160 & & & & 160 & \\
\hline 22 Cahit Arf & 160 & & & & 160 & \\
\hline $23 \quad$ Itri & 160 & & & & 160 & \\
\hline 24 Mimar Kemalettin & 160 & & & & 160 & \\
\hline 25 Yunus Emre & 160 & & 212 & 212 & & \\
\hline $26 \begin{array}{l}\text { Ahmet Hamdi } \\
\text { Tanpınar }\end{array}$ & & & 188 & 188 & & \\
\hline 27 Abdullah Gül & 200 & & & & & 200 \\
\hline 28 Şükrü Andaç & 200 & & & & & 200 \\
\hline 29 Koray Löker & 200 & & & & & 200 \\
\hline $30 \quad$ Selen Iş1k(Pucca) & 200 & & & & & 200 \\
\hline 31 Öykü Gürman & 200 & & & & & 200 \\
\hline 32 Berk (Gürman) & 200 & & & & & 200 \\
\hline 33 Mustafa Kara & 202 & & & 202 & & \\
\hline
\end{tabular}

Tablo 14'e bakıldığında ilgili kitabın C+ seviyesinde toplam $33(32,01)$ şahsiyete yer verildiği görülmektedir. Verilen şahsiyetlerin 27 'sinden sadece isim olarak bahsedilirken 8 'i ise doğrudan metnin kendisi ile ilgili verilmiștir. "Metinde özellikleri verilmiş" kategorisinde ise herhangi bir bulgu tespit edilememiştir. İlgili şahsiyetlerin 4'ü okuma, 14'ü dinleme ve 6'sı ise konuşma becerisi aracılı̆̆ ile verilmiştir. "Metin bağlamında işlenmiş" kategorisinde tespit edilen 8 şahsiyetin 3'ü dinleme, 5'i okuma becerisi aracılığı ile verilmiştir. 


\begin{tabular}{|c|c|c|c|c|c|c|}
\hline & \multicolumn{6}{|c|}{ Tablo 15: Şahsiyetlerin, Yedi İklim C2 Ders Kitabında Veriliş Şekli ve Oranı } \\
\hline & \multirow{4}{*}{$\begin{array}{l}\text { Kitabın Adı: } \\
\text { Şahsiyet }\end{array}$} & \multicolumn{5}{|c|}{ Yedi İklim Türkçe C2 Ders Kitabı } \\
\hline & & \multicolumn{3}{|c|}{ Metinde Yer Veriliş Şekli } & \multicolumn{2}{|c|}{$\begin{array}{c}\text { Metnin İlgili olduğu } \\
\text { Beceri }\end{array}$} \\
\hline & & $\begin{array}{l}\text { İsim } \\
\text { olarak yer } \\
\text { verilmiş }\end{array}$ & $\begin{array}{l}\text { Metinde özelliklerine yer } \\
\text { verilmiş }\end{array}$ & $\begin{array}{l}\text { Metin bağlamında } \\
\text { işlenmiş }\end{array}$ & Okuma & Dinleme \\
\hline & & \multicolumn{5}{|c|}{ Sayfa numarası } \\
\hline 1 & Emine Işınsu & & & 10 & & 10 \\
\hline 2 & Yunus Emre & & 10 & 12 & 12 & 10 \\
\hline 3 & Tapduk Emre & & 12 & & 12 & \\
\hline 4 & Turan Oflazoğlu & & & 15 & & 15 \\
\hline 5 & Dede Efendi & & 16 & & 16 & \\
\hline 6 & Mevlana & 16 & & 92 & 16,92 & \\
\hline 7 & Cengiz Aytmatov & & 19 & 20 & 20 & 19 \\
\hline 8 & Can Yücel & & & 30 & & 30 \\
\hline 9 & Neyzen Tevfik & & & 32 & 32 & \\
\hline 10 & Nef'i & 32 & & & 32 & \\
\hline 11 & Eşref & 32 & & & 32 & \\
\hline 12 & $\begin{array}{l}\text { Namdar Nabi } \\
\text { Karatay }\end{array}$ & 34 & & & & 34 \\
\hline 13 & Şair Eşref & & & 35 & 35 & \\
\hline 14 & Şair Naif & & 35 & & 35 & \\
\hline 15 & Aşık Veysel & 37 & & & 37 & \\
\hline 16 & Deliktaşlı Ruhsati & 37 & & & 37 & \\
\hline 17 & Şarkışlalı Serdari & 37 & & & 37 & \\
\hline 18 & Feyadi & 37 & & & 37 & \\
\hline 19 & Âtıl Kutoğlu & & & 62 & & 62 \\
\hline 20 & $\begin{array}{l}\text { Fatih (Sultan } \\
\text { Mehmet) }\end{array}$ & 64 & & & 64 & \\
\hline 21 & $\begin{array}{l}\text { Kanuni S. } \\
\text { Süleyman }\end{array}$ & 64 & & & 64 & \\
\hline 22 & $\begin{array}{l}\text { Tasasız Raziye } \\
\text { Sultan }\end{array}$ & 64 & & & 64 & \\
\hline 23 & Türkan Şoray & & & 72 & & 72 \\
\hline 24 & Evliya Çelebi & 84 & & & & 84 \\
\hline 25 & Alâeddin Keykubat & 84,92 & & & 92 & 84 \\
\hline 26 & Orhan Bey & 84 & & & & 84 \\
\hline 27 & Şeyh Küşteri & 84 & & & & 84 \\
\hline 28 & Sultan Veled & 92 & & & 92 & \\
\hline 29 & Feridüddin Attat & 92 & & & 92 & \\
\hline 30 & $\begin{array}{l}\text { Mükrimin Halil } \\
\text { Yınanç }\end{array}$ & & & 97 & 97 & \\
\hline 31 & Hilmi Ziya Ülken & 97 & & & 97 & \\
\hline 32 & $\begin{array}{l}\text { Sabri Esat } \\
\text { Siyavuşgil }\end{array}$ & 97 & & & 97 & \\
\hline 33 & $\begin{array}{l}\text { Tarık Dursun } \\
\text { Kakınç }\end{array}$ & & 142 & & 142 & \\
\hline 34 & Oktay Akbal & & 143 & & 143 & \\
\hline
\end{tabular}

Tablo 15'e bakıldığında ilgili kitabın C2 seviyesinde toplam 34 (\%20,73) şahsiyete yer verildiği görülmektedir. Bunların 20'sinden sadece isim olarak bahsedilirken, 7'sinin metin içerisinde özelliklerine yer verilmiș, 11'inde ise metnin doğrudan kendisi ile ilgili oluşturulmuș olduğu tespit edilmiştir. Elde edilen bulgulara beceri odaklı bakılırsa isim olarak bahsedilen 20 
şahsiyetin 15 'i okuma, 5'i dinleme becerisi aracılı̆̆ 1 ile verilmiştir. "Metinde özelliklerine yer verilmiş" kategorisinde tespit edilen 7 şahsiyetin tamamı okuma becerisi aracilığı ile verilirken Cengiz Aytmatov ve Yunus Emre aynı zamanda dinleme becerisi aracılığı ile de verilmiştir.

Tablo 14 ve 15 'e birlikte bakıldığında her iki kitapta da şahsiyetlere yer verme oranının birbirine çok yakın olduğu, sadece "Metinde özelliklerine yer verilmiş" kategorisinde İstanbul C1+ kitabında herhangi bir bulgu olmadığı söylenebilir. Bu duruma ek olarak Yedi İklim kitabı şahsiyetleri sadece okuma ve dinleme becerisi aracılığı ile verirken İstanbul ders kitabı şahsiyetlere konuşma becerisi içerinde de yer vermiştir. Bu durum, şahsiyetlerin veriliş şekli bakımında İstanbul'u bir adım öne çıkarmaktadır.

\section{Sonuç, Tartışma ve Öneriler}

Ders kitaplarında yer alan veya alacak şahsiyetlerin öğrencilere öğretimi kültür aktarımı açısından üzerinde ayrıca durulması gereken bir konudur. Bunun en temel nedeni ise sanat, tarih, spor, iş dünyası, siyaset, sağlık, müzik, edebiyat vb. alanları temsil eden büyük kültürün (K) aktarımı genelde bu alanlarda belirli bir temsil gücü olan bireyler aracılığı ile yapılmaktadır. Yabancı dil olarak Türkçe öğretiminde herhangi bir alanda yaptığı çalışmalar ile Türk toplumunda yer edinmiş şahsiyetlerin öğretimi, öğrenicilerin Türkleri ve Türk kültürünü tanımaları konusunda fayda sağlayacaktır. Bu bağlamda ders kitapları hazırlanırken kültür aktarımının beş bileşeninden biri olan "kişiler"e muhakkak yer verilmesi gerektiği bilinmeli ve belirli bir sistem ve anlayış doğrultusunda yapılmalıdır. İlgili ders kitaplarında şahsiyetlere belirli bir sitem ve anlayış doğrultusunda yer verilip verilmediğini ortaya çıkarmak amacı ile tasarlanan bu çalışmada her iki ders kitabının bütün seviyelerinin toplamında farklı kategorilerde İstanbul setinde 97, Yedi İklim setinde 164 şahsiyete yer verildiği tespit edilmiştir. Ders kitaplarında yer alan şahsiyetlerin veriliş biçimlerine dair ulaşılan bulgulara bakıldığında ulaşılan sonuçlar şöyledir: İstanbul setinde yer alan 97 şahsiyetin 66'sına $(\% 68,04)$, Yedi İklim'de yer alan 164 şahsiyetin 67'sine $(\% 40,85)$ isim olarak yer verilmiştir. İstanbul setinde $17(\% 17,52)$, Yedi İklim'de ise $38(\% 62,32)$ şahsın metinde özelliklerine yer verilmiştir. İstanbul setinde $20(\% 13,4)$, Yedi İklim setinde ise 59 şahsiyet, metin bağlamında işlenmiştir. İlgili oranlara bakıldığında iki set arasındaki farkın bu denli fazla olması her iki setin de kişiler bileşeni bağlaımda bir ölçüt dikkate alınmadan oluşturulduğunu göstermektedir.

Araştırmadan elde edilen bulgular, her iki set bağlamında karşılaştırılarak yorumlandığında A1, A2, B1 ve B2 seviyelerinde Yedi İklim ders kitabında şahsiyetlerin veriliş sıklığ 1 ve veriliş biçimi İstanbul kitabından fazla olsa da $\mathrm{C} 1$ ve $\mathrm{C} 2$ seviyelerinde her iki kitapta şahsiyetlerin veriliş sıklı̆ 1 birbirine çok yakındır. Şahsiyetlerin veriliş biçimi üzerinden bir değerlendirme yapılacak olursa Yedi İklim kitapları sadece okuma ve dinleme becerisi üzerinden şahsiyetlere yer verirken İstanbul kitabının özellikle $\mathrm{C} 1$ ve $\mathrm{C} 1+$ seviyelerinde bütün beceriler üzerinden şahsiyetlere yer verdiği sonucuna ulaşılmıştır. Özellikle İstanbul setinde yer verilen şahsiyetlerin sadece dinleme ve okuma becerisi üzerinden değil konuşma ve yazma becerilerinin üzerinden de verilmesi oldukça önemli bir husustur. Her iki sete, yer verdikleri şahsiyetlere cinsiyet bağlamında bakıldığında kadın şahsiyetlere çok az yer verildiği tespit edilmiştir. Bu da ders kitaplanı açısından oldukça önemli bir eksikliktir.

Alanyazındaki ders kitaplarını, yer verdikleri kültürel içerikler bağlamında inceleyen çalışmalara ve bu çalışmanın bulgularına bakıldığında ders kitapları oluşturulurken kişiler bileşeni bağlamında belirli bir sistematik ve anlayışın olmadığı görülmektedir. Bu çerçevede Şimşek (2018) çalışmasında $\mathrm{EF}^{1}{ }^{1}$ te kültürel içeriğe Anglo-Amerikan yüzler egemenken, $\mathrm{YH}^{2}{ }^{2}$ te Türk insanları $(\mathrm{f}=10)$ azınlıkta ve kaynak kültürlerin şöhretleri $(\mathrm{f}=85)$ baskın olduğunu, Türk kişiliklerin, hem çok sınırlı bir oranda hem de unumlarında isimlerini izleyen yüzeysel bir açıklamayla yetinildiği, öte yandan, Batılı ve çoğunluğu İngilizce konuşan ülkelerin ediplerinin, düşünürlerinin,

\footnotetext{
${ }^{1}$ English File Upper-Intermediate 3. basim

${ }^{2}$ Yeni Hitit 3. basim
}

Turkish Studies - Education, 15(3) 
müzisyenlerinin, oyuncularının, bilim adamlarının ve yatırımcılarının dünya kültürüne katkılarıyla birlikte sunulduğu tespit edilmiştir. Kılıç (2019)'ın çalışmasında ise incelenen ders kitaplarında TYB $1^{3}$ 'de geçen 60 ögenin (şahsiyetin-kişinin) 39'unun Türk kültürüne ait olduğunu, Bunun da yüzde olarak \%65'e karş1lık geldiğini; ATÖB ${ }^{4}$ 'de 93 ögenin 27 'sinin Türk kültür ögesi (şahsiyeti) olduğunu, bunun da yüzde olarak \%29'a karş1lı geldiğini tespit etmiş ve TYB1'de Türk kültürü ögesinin (şahsiyeti) çok fazla olduğunu, ATÖB1'de ise yabanc1 kültür ögesinin fazla olduğunu bu nedenle bu alt başlıktaki ögelerin dağılımı her iki kitapta da orantılı olmadığını belirtmiştir. Gürsoy ve Güleç (2015) çalışmasında edebiyat-sanat, spor, müzük ile ilgili kültürel ögeleri tespit ederken bu alanlarda ön plana çıkmış şahsiyetlerin verildiğini tepit etmişler ve edebiyat, sanat ve müzik başlı̆g 1 altında kültürel ögelerin az yer aldığı sonucuna ulaşmışlardır. Özyurt Gülen (2019) çalışmasında, incelediği Yeni Hitit Yabancılar İçin Türkçe A1-A2, B1, B2-C1 ders kitapları ve A1-A2 çalıșma kitabında, özellikle kişilere ait bilgilerin yüzeysel verildiği, açıklayıcı ve tanımlayıcı detaylara yer verilmediği ve işlenen konuların bir kapsam ve sisteme göre belirlenmediğini tespit etmiş ve ayrıca incelediği bir sette Kemal Atatürk'e yer verilmediğini ve bunun önemli bir eksiklik olduğunu belirtmiştir. Aynı şekilde Erdal vd. (2019: 246) inceledikleri bazı ders kitaplarında yer alan ünlülerin hangi alanlarda başarılı olduklarının yazılmadığını, bazı kitaplarda da ünlülerin adının yer almadığı sadece görsellerinin verilmesiyle yetinildiğini tespit etmiş ve dil öğretmenin kültürü de öğretmek olduğu gerçeği gözardı edilmeden, yabancılara Türkçe öğretmek için hazırlanan ders kitaplarında Türk kültürünü temsil eden sanatçılara, Türk bilim insanlarına ve Mustafa Kemâl Atatürk'e ilişkin bilgiler verilmesi ve bu bilgilerin görsellerle desteklenmesi gerektiğini belirtmişerdir. Bu da ders kitaplarında yer verilecek şahsiyetlerin seçiminde bir sistematiğin ve anlayışın olması gerektiğini ve bu hususta ders kitabı yazarlarının sadece kendi dünya görüşlerine bırakılmaması gerektiğinin açıkça kanitidir.

Yukarıdaki sonuçlara ek olarak, ders kitaplarında kadın şahsiyetlere, erkeklere göre çok az yer verildiği belirlenmiştir. Oysaki Türk toplumunun kadına verdiği önem ve kadınların toplumdaki başarısı göz önünde bulundurulduğunda ders kitaplarında ortaya çıkan bu durumun kültür aktarımı açısından önemli bir eksiklik olduğu söylenebilir. Bu bağlamda Cunningsworth (1995)'un kültürel içeriği değerlendirmek için önerdiği sekiz ölçütten biri olan, "Ders kitabının her alanında kadınlara erkeklere eşit önem verilir mi?" (akt, Liu, 2016: 843) ölçütü bağlamında bir eksiklik olduğu görülmektedir.

Yukarıdaki bilgi ve yorumlara ek olarak bugün Türk dizi ve müzik sektörünün dünya piyasasındaki atılımları insanların yönünü Türkiye'ye ve Türkçeye çevirmelerindeki en önemli unsurların başında geldiği (Deniz, 2010; Nuroğlu, 2013; Öztürk ve Atik, 2016) Türk dizileri sayesinde Türk toplumuna karşı bir merak ve özdeşim uyandığı, özellikle Tuba Büyüküstün, Beren Saat, Bergüzar Korel, Kıvanç Tatlıtuğ, Songül Öden, Kenan İmirzalioğlu gibi oyuncuların son derece popüler olduğu belirtilmektedir. Bu ise yukarıda da tekrarlandığı üzere Türkiye ve Türkçeye olan ilgi ve merakı artırmakta hatta ön yargıları da en aza indirmektedir. Bu bağlamda bir yorum yapıldığında ilgili dizilerin izlenmesini sağlayan temel faktörlerden biri şüphesiz oyunculardır. Bu nedenle seçilen şahsiyetin insanlardaki alg1 üzerinde doğrudan bir etkisinin olduğu söylenebilir. Tüm bunlar sevindirici olsa da elbette Türk kültürünü sadece dizi ve filmler ve bu filmlerdeki karekterlerin üzerinden vermek yetersiz hatta yanlış olacaktır. Bu nedenle hem popülerliği yüksek olan bu tür şahsiyetlerin tanıtımı hem de Türk kültürü ve hayatı içinde önemli yeri olan şahsiyetlerin ders kitaplarında kültür aktarım aracı olarak kullanımı, Türkçeye ve Türklere bakış açısında olumlu değişikliklere imkân yaratacaktır. Bu bağlamda ilgili ders kitapları bu bakış açısından kopmadan oluşturulursa dil öğretiminde sistemli bir ilerleme de kaydedilmiş olacaktır.

\footnotetext{
${ }^{3}$ Türkçeye Yolculuk B1 ders kitabı

${ }^{4}$ Altay Türkçe Öğreniyorum B1 ders kitabı
} 
Yukarıdaki bilgi ve bulgular 1şığında çalışmanın giriş bölümünde de ifade edildiği üzere bu çalışmanın, ilgili alanda ders kitaplarında yer alan veya alması gereken şahsiyetlerin kimler olması, hangi beceriler üzerinden ne sıklıkla, nasıl verilmesi gerektiğine yönelik bundan sonraki yapılacak çalışmalara 1şık tutacağı düşünülmektedir. Bu bağlamda ilgili çalışma sonuçları kapsamında verilen öneriler aşağıdaki gibidir:

- Ders kitaplarında yer alacak şahsiyetlerin kimler olması gerektiğine yönelik çeşitli çalışmalar yapılmalı ve bu çalışmalarda, Türkiye'de kültürel kimliği ile ön plana çıkmış insanların, alanda ders veren öğretmenlerin, akademisyenlerin vb. görüşlerine başvurularak ders kitaplarında yer verilmesi gereken şahsiyetler belirlenmelidir.

- Yabancı dil olarak Türkçe öğretimi ile ilgili yazılan ders kitaplarında yer alacak şahsiyetlerin tematik/kategorik bir şekilde verilmesine dikkat edilmelidir.

- Ders kitaplarında, şahsiyetlere yer verirken mümkün olduğunca her alandan (tarih, siyaset, edebiyat, sinema vb.) eşit oranda dağılım olmasına dikkat edilmelidir.

- Şahsiyetlerin veriliş biçimleri muhakkak belirlenmelidir. Örneğin bu çalışmada ders kitapları incelenmiş ve "sadece isim olarak yer verilenler", "metinde özelliklerine yer verilenler" ve "metin bağlamında işlenmiş" vb. kategoriler tespit edilmiştir. Benzer şekilde diğer kitaplar da incelenip ulaşılan sonuçlar karşılaştırılarak ders kitaplarında şahsiyetlerin veriliş amaçları dikkate alınarak belirli bir format oluşturulmalıdır.

- $\mathrm{Bu}$ araştırmada, her iki ders kitabındaki bütün şahsiyetlerin \%60’ına sadece isim olarak yer verilmiştir. $\mathrm{Bu}$ açıdan bakıldığında bu şahsiyetlere sadece isim olarak yer verildiği için öğrenciler tarafından ne kadar tanındıklarına dair bir bilgiye ulaşmak zordur. Aynı zamanda öğretmenlerin derslerde bu şahsiyetleri detaylı anlatıp anlatmadıkları da bilinmemektedir. Bu nedenle her iki durumun da anlaşılmasına yönelik akademik çalışmalar yapılmalıdır.

- Şahsiyetlere yer verilirken cinsiyet eşitliği de dikkate alınmalı ve bu bağlamda kadın şahsiyetlere erkeklerle aynı oranda yer verilmelidir.

- Alanda kullanılan setler ile yabancı dillerin öğretiminde (özellikle İngilizce) kullanılan setler yer verilen şahsiyetlerin oranı, dağılımı vb. açılardan karşılaştırmalı olarak incelenmelidir.

- Ders kitaplarındaki yer verilen şahsiyetlerin öğretmenler tarafından tanınırlıklarına yönelik araştırmalar yapılmalıdır. Çünkü özellikle her iki sette de yer alan bazı şahsiyetlerin öğretmenler tarafından bilinirliklerinin çok düşük olduğu tahmin edilmektedir.

- Bu çalışmada kitap setleri Türk şahsiyetler bağlamında incelenmiştir. Ders kitaplarında yer alacak farklı milletlerden önemli veya ünlü şahsiyetlere çokkültürlülük bağlamında hangi oranda, ne şekilde yer verilmesi gerektiğine veya verildiğine yönelik akademik çalışmalar yapılmalıdır.

\section{Kaynakça}

Açık, F. ve Demir, A. (2011). Türkçenin yabancı dil olarak öğretiminde kültürlerarası yaklaşım ve seçilecek metinlerde bulunması gereken özellikler. TÜBAR, 30, 51-72.

Akbulut, S., ve Yayl1, D. (2015). Yabancı dil olarak türkçe öğretimi a1-a2 düzeyi ders kitapları üzerine bir izlence çalışması. Erzincan Üniversitesi Sosyal Bilimler Enstitüsü Dergisi, 2, 3546.

Akkoyunlu, B. (2019). Yedi İklim yabancı dil olarak Türkçe setindeki kültürel varllğgn incelemesi. Yayımlanmamış yüksek lisans tezi, Hacettepe Üniversitesi Türkiyat Araştırmaları Enstitüsü. 
Andarab, M. S. (2015). Representation of the characters in the claimed English as an international language-targeted coursebooks. Studies in English Language Teaching, 3(4), 294.

Asemota, E. H. (2015). Language, the individual, society and culture constitute a unique approach, congenial for language teachers. British Journal of English Linguistics, 3(3), 14-22.

Barcın, S. (2018). Türk Soylulara Türkçe öğretiminde kültür aktarım aracı olarak atasözleri ve deyimlerin kullanımı: Kırgızistan-Türkiye Manas Üniversitesi Altın Köprü Türkçe öğretimi ders kitab1 (B1 seviyesi). Aydın Tömer Dil Dergisi, 3(2), 1-16.

Barcın, S. (2019). Kırgızistan- Türkiye Manas Üniversitesi Altın Köprü Türkçe öğretimi ders kitabında (B2 seviyesi) yer alan kültür ögeleri. Uluslararası Sosyal Bilimler Akademik Araştırmalar Dergisi, 3 (2), 39-50.

Baskın, S. (2018). Which cultural aspects do the textbooks of teaching Turkish to foreigners transfer? Advances in Language and Literary Studies, 9(2), 131-137.

Biçer, N. ve Batdı, V. (2019). An investigation of textbooks used to teach Turkish as a foreign language with Rasch measurement model and Maxqda. Journal of Language and Linguistic Studies, 15(4), 1269-1286. Doi: 10.17263/jlls.668420

Bowen, G. A. (2009). Document analysis as a qualitative research method. Qualitative research journal, 9(2), 27-40.

Boztilki, G. (2018). Gazi Üniversitesi Tömer B1 seviyesi kitabının değerler eğitimi bakımından incelenmesi. Journal of Human Sciences, 15(2), 755-765.

Bölükbaş F ve Keskin F. (2010). Yabancı dil olarak Türkçe öğretiminde metinlerin kültür aktarımında işlevi. Turkish Studies, 5(4), 221-235.

Büyüköztürk, Ş., vd (2013). Bilimsel araştırma yöntemleri. Pegem Akademi Yay.

Byram, M. (1997). Teaching and assessing intercultural communicative competence. Clevedon: Multilingual Matters.

Byram, M., Morgan, C. ve Colleagues. (1994). Teaching-and-learning language-andculture. Clevedon: Multilingual Matters.

Byrd, P. (2001). "Textbooks: Evaluation for selection and analysis for implementation." In M. C. Murcia (Ed.), Teaching English as a second or foreign language (pp. 415-427). Heinle, Cengage Learning.

Chen B. B. (2004). A survey on cultural learning and its variables analysis. Journal of Xi'an International Studies University, 12(3), 21-24.

Çangal, Ö. (2012). Yabancılara türkçe öğretiminde kültür aktarıcısı olarak türküler. Gazi Üniversitesi Türkçe Araştırmaları Akademik Öğrenci Dergisi, 2(2), 9-20.

Çelik, S. ve Erbay, Ş. (2013). Cultural perspectives of turkish elt coursebooks: do standardized teaching texts incorporate intercultural features? Eğitim ve Bilim, 38 (167), 336-351.

Çetinoğlu, G. ve Güllülü, M. (2018). A2 seviyesi için hazırlanmış İstanbul Yabancılara Türkçe Öğretim Seti ve Yunus Emre Enstitüsünün Yedi İklim Setinin kültürel aktarım açısından karşılaştırılması. Turkish Studies, 13(4), 321-344.

Demir, D. (2014). Yabancı dil olarak Türkçe öğretim ders kitaplarının kültürel içeriği. Hacettepe Üniversitesi Yabancı Dil Olarak Türkçe Araştırmaları Dergisi, 1, 53-61.

Demir, N. (2014). Yabancı dil olarak Türkçe öğretim kitaplarının kültürel içeriği. Hacettepe Üniversitesi Yabancı Dil Olarak Türkçe Araştırmaları Dergisi, 1, 53-61. 
Deniz, A. Ç. (2010). Gümüş dizisinin Arap kamuoyuna etkileri bir sosyal medya incelemesi. Uşak Üniversitesi Sosyal Bilimler Dergisi, 3(1), 50-67.

Dewi, K.C. (2016). Cultural contents in an English language teaching (ELT) textbook: a case of Indonesia. Yayımlanmamış yüksek lisans tezi, Sebelas Maret University, Solo: Indonesia.

Fişekçioğlu, A. (2019). Yabancı dil olarak türkçe ögretiminde diller için Avrupa ortak öneriler çerçevesi ölçütlerine göre Türk kültürü tanımlayıcılarının oluturulması: B1 dil düzeyi model önerisi. Yayımlanmaış doktora tezi, Çanakkale Onsekiz Mart Üniversitesi Eğitim Bilimleri Enstitüsü, Çanakkale.

González, A. (2006). "On materials use training in EFL teacher education: Some reflections." Profile, Issues in Teacher' Professional Development, 7, 101-115.

Göçer, A. (2007). Türkçenin yabancı dil olarak öğretiminde kullanılan ders kitaplarının ölçme ve değerlendirme açısından incelenmesi. Dil Dergisi, 137, 30-48.

Gökalp, Z. (1997). Türkçülüğün Esasları. İnkîlap Kitabevi.

Gün, M., Akkaya, A. ve Kara, Ö. T. (2014). Yabancılara Türkçe öğretimi ders kitaplarının Türkçe öğretim merkezlerinde görev yapan öğretim elemanları açısından değerlendirilmesi. Turkish Studies 9(6), 1-16.

Güncel Türkçe Sözlük, (2020). “Kültür” https://sozluk.gov.tr/?kelime=k\%C3\%BClt\%C3\%BCr

Gürsoy, S. ve Güleç İ. (2015). "Yabancılara Türkçe ögretiminde kültürel ögelerin aktarımı: Gökkuşağı Türkçe öğretim seti temel seviye örneği”, IV. Sakarya'da Eğitim Araştırmaları Kongresi Bildiri Kitab1, 98-119. ISBN: 9786054735594.

Han, J. ve Zhang, L. (2020). Teaching culture in TEFL. Creative Education, 11, 447-451. https://doi.org/10.4236/ce.2020.114032

Hasırcı, S. (2019). Yabancılara Türkçe öğretimine yönelik ders kitaplarının konuşma becerisi açısından karşılaştırılması. Uluslararası Türkçe Edebiyat Kültür Eğitim Dergisi, 8(2), 10681098.

İltar, L. ve Dündar, S. A. (2018). Suriyeli öğrencilere Türkçenin yabancı dil olarak öğretiminde kullanılan öğretim setleri hakkında karşılaştırmalı bir değerlendirme çalışması. 21. Yüzyılda Eğitim ve Toplum Eğitim Bilimleri ve Sosyal Araştırmalar Dergisi 7(20), 523-539.

İşcan, A. ve Yassıtaş, T. (2018). Yabancı dil olarak Türkçe öğretimi ders kitaplarında kültür aktarımı: Yedi İklim Türkçe öğretim seti örneği (B1-B2 Düzeyi). Aydın TÖMER Dil Dergisi, 3(1), 47-66.

Kalenderoğlu, İ. (2017). Türkçenin yabancı dil olarak öğretiminde kullanılan temel düzey (a1, a2) ders kitaplarında kültür aktarım1. 21. Yüzyılda Ĕgitim ve Toplum Eğitim Bilimleri ve Sosyal Araştırmalar Dergisi, 4(12),73-83.

Karababa, Z. C. (2009). Yabancı dil olarak Türkçenin öğretimi ve karşılaşılan sorunlar. Ankara Üniversitesi Eğitim Bilimleri Fakültesi Dergisi, 42(2), 265-277.

Karababa, Z. C., ve Üstünsoy Taşkın, S. (2012). Yabancı dil olarak Türkçe öğretiminde kullanılan ders kitaplarının öğretmen görüşleri çerçevesinde değerlendirilmesi. Dil Dergisi, 157, 65-80.

Kelime Erdal. (2019). Yabancı dil olarak Türkçe öğretimi A1 ve A2 düzeyi ders kitaplarının tanınmış kişiler açısından incelenmesi. Akademik Bakış Uluslararası Hakemli Sosyal Bilimler Dergisi, 72, 237-248. 
Kılcan, B., Akbaba, B. ve Gülbudak, B. (2017). Altıncı ve yedinci sınıf öğrencilerinin Hoca Ahmed Yesevî algıları. Journal of History Culture and Art Research, 6(2), 549-564. doi:http://dx.doi.org/10.7596/taksad.v6i2.809

Kılıç, F. (2019). Kültürel ögeler açısından yabancı dil olarak Türkçe öğretiminde kaynak incelemesi: Türkçeye yolculuk B1-B2 ve Altay Türkçe Öğreniyorum B1-B2 örnekleri. Yayımlanmamış Yüksek Lisans Tezi. Sakarya Üniversitesi Eğitim Bilimleri Enstitüsü, Sakarya.

Kılıçkaya, F. (2004). Guidelines to evaluate cultural content in textbooks. The Internet TESL Journal, 10(12), 38-48.

Kim, S.Y and Paek, J. (2015). An analysis of culture-related content in English textbooks. Linguistic Research 32 (Special Edition), 83-104.

Köşger, G. (2015). Yabancı dil öğretiminde kültür aktarımı: Fransız dili örneği. Ahi Evran Üniversitesi Kırşehir Eğitim Fakültesi Dergisi, 16(2), 409-421.

Kutlu, A. (2015). Yabancılara türkçe öğretiminde kültürün araç olarak kullanımı: gazi yabancılar için türkçe öğretim seti örneği (B1-B2 seviyesi). Kastamonu Eğitim Dergisi, 23(2), 697-710.

Lappalainen, T. (2011). Presentation of the American culture in EFL textbooks: An analysis of the cultural content of Finnish EFL textbooks for secondary and upper secondary education. Yayımlanmamış yüksek lisans tezi, University of Jyväskylä: Finland.

Lee, K-Y. (2009). Treating culture: what 11 high school efl conversation textbooks in South Korea do. English Teaching: practice and Critique, 8(1), 76-96.

Liu, K. (2016). Prioritizing Criteria for Evaluating Cultural Contents in EFL Textbooks through AHP. Journal of Language Teaching and Research, 7(5), 841-850.

Matsumoto, D. (1996) Culture and Psychology. Pacific Grove, CA: Brooks/Cole.

Miles, M. B. ve Huberman, A. M. (1994). An expanded sourcebook: Qualitative data analysis. Thousand Oaks, CA: SAGE Publications, Inc.

Moralı, G. ve Göçer, A. (2019). Yabancı dil olarak Türkçe öğretiminde kültür paylaşımına yönelik öğretmen görüşleri. Ana Dili Eğitimi Dergisi, 7(4), 1115-1129.

Mutlu, H. H. Ve Şet, G. (2020). Yabancı dil olarak Türkçe öğretiminde kullanılan c1 seviye ders kitaplarındaki kültür unsurlarının incelenmesi (Gazi yabancılar için türkçe - İstanbul yabancılar için Türkçe). Dil Dergisi, 171(1), 91-107.

Nuroğlu, E. (2013). Dizi turizmi: Ortadoğu ve Balkanlar'dan gelen turistlerin Türkiye'yi ziyaret kararında Türk dizileri ne kadar etkili? 5. Uluslararası İstanbul İktisatçılar Zirvesi Bildiri Kitab1,https://www.researchgate.net/publication/261002399

Okur, A. (2012). Haci Bektaş Velî ve ilgili kavramların tanınabilirlik algısı üzerine bir araştırma ve öğretim programlarındaki (MEB) durumu. Türk Kültürü ve Haci Bektaş Veli Araştirma Dergisi, 64, 199-218.

Okur, A., ve Keskin, F. (2013). Yabancılara Türkçe öğretiminde kültürel ögelerin aktarımı: İstanbul yabanc1lar içinmTürkçe öğretim seti örneği. The Journal of Academic Social Science Studies, 6(2), 1619-1640.

Ökten, C. E., ve Kavanoz, S. (2014). Yabancı dil olarak Türkçe öğretimini hedefleyen ders kitaplarında kültür aktarımı. Turkish Studies, 9(3), 845-862.

Ömeroğlu, E. (2016). Yabancılara türkçe öğretimi için hazırlanmış ders kitaplarının incelenmesi. Yayımlanmamış doktora tezi, Sakarya Üniversitesi Eğitim Bilimleri Enstitüsü, Sakarya. 
Özdemir, C. (2013). Yabancilara Türkçe öğretiminde ders malzemelerinin önemi ve işlevsel ders malzemelerinin nitelikleri. Turkish Studies, 8(1) 2049-2056.

Özkan, R. (2014). Eğitim fakültesi öğrencilerinin Haci Bektaş Veli’yi tanıma düzeyi ve Bektaşilik hakkındaki tutumlarının belirlenmesi. Zeitschrift für die Welt der Türken, 6(1), 241-255.

Öztürk, M. ve Atik, A. (2016). Ulusal pazardan küresel pazarlara uzanan süreçte Türk dizilerinin gelişimi. Maltepe Üniversitesi İletişim Fakültesi Dergisi, 3(2),66-82.

Özyurt Gülen, D. (2019). Kültürlerarası iletişim kapsamında yabancı dil ögretim yolu ile kültür aktarımı ve duyarlılık kazanımı: örnek kitap incelemesi. Yayımlanmamış yüksek lisans tezi, Ankara Üniversitesi Sosyal Bilimler Enstitüsü, Ankara.

Peterson, B. (2004). Cultural intelligence: A guide to working with people from other cultures. Yarmouth, ME: Intercultural Press.

Rodríguez, G. (2010). English textbooks for teaching and learning english as a foreign language: do they really help to develop communicative competence? Educación y Educadores, 13(3),2336.

Şimşek, M. R. (2018). Yabancılar için İngilizce ve Türkçe ders kitaplarındaki kültürel içeriklerin karş1laştırmas1. Türk Dünyası Sosyal Bilimler Dergisi, 84, 301-327.

Şimşek, R. (2016). Yabancılara Türkçe öğretiminde kullanılan ders kitaplarının temel dil becerileri bağlamında karşılaştırmalı olarak incelenmesi. Yayımlanmamış yüksek lisans tezi, Nevşehir Hacı Bektaş Veli Üniversitesi, Nevşehir.

Tansrıverdi, E. A. ve Tüm, G. (2016). Yabancılar için Türkçe öğretimi ders kitaplarında yer alan yazma etkinliklerinde özgünlük. Turkophone, 3, 18-36,

Tanyıldızı, İmik, N. (2011). Türk kültürünün gençlere tanıtımında medyanın rolü: Haci Bektaş Velî, Mevlâna ve Yunus Emre üzerine bir araştırma. Türk Kültürü ve Haci Bektaş Veli Araştirma Dergisi, 59, 101-118.

Tokcan, H. ve Kolyiğit, E. (2017). Türk tarihinde yer alan önemli kadın şahsiyetler hakkında öğrenci bilgi düzeyleri. Uluslararası Sosyal Bilgilerde Yeni Yaklaşımlar Dergisi, 1, 31-41.

Toprak, F. (2011). Yabancılara Türkçe Öğretimi kitaplarındaki okuma parçaları ve diyalogları üzerine bir değerlendirme. Selçuk Üniversitesi Türkiyat Araştırmaları Dergisi, 29, 11-24.

Ulum, G. Ö. (2018). Ideological and hegemonic practıces in globally and locally written efl textbooks. Yayımlanmamış doktora tezi, Çanakkale Onsekiz Mart Üniveristesi. Eğitim Bilimleri Enstitüsü, Çanakkale.

Yaylı, D. ve Yaylı, D. (2018). Yabancılara Türkçe öğretimi ders kitaplarında yazma etkinliklerinin değerlendirilmesi (Yedi İklim Türkçe örneği). Pamukkale Üniversitesi Eğitim Fakültesi Dergisi, 44, 132-145.

Yımaz, F. (2015). Yeni Hitit yabancılar için Türkçe öğretim setindeki görsellerde kültür akratırımı. Uluslararası Sosyal Araştırmalar Dergisi, 8(37), 841-849.

\section{Araştırmada İncelenen Ders Kitapları}

İstanbul Yabancılar İçin Türkçe Ders Kitabı A1 (2012). İstanbul: Kültür Sanat Basımevi. İstanbul Yabancılar İçin Türkçe Ders Kitabı A2 (2012). İstanbul: Kültür Sanat Basımevi. İstanbul Yabanc1lar İçin Türkçe Ders Kitabı B1 (2012). İstanbul: Kültür Sanat Basımevi. İstanbul Yabancılar İçin Türkçe Ders Kitabı B2 (2012). İstanbul: Kültür Sanat Basımevi. İstanbul Yabancılar İçin Türkçe Ders Kitabı C1 (2012). İstanbul: Kültür Sanat Basımevi. İstanbul Yabancılar İçin Türkçe Ders Kitabı C+ (2012). İstanbul: Kültür Sanat Basımevi. 
Yunus Emre Enstitüsü Yedi İklim Türkçe A1 Ders Kitab1, (2014). Yunus Emre Enstitüsü. Yunus Emre Enstitüsü Yedi İklim Türkçe A2 Ders Kitab1, (2014). Yunus Emre Enstitüsü. Yunus Emre Enstitüsü Yedi İklim Türkçe B1 Ders Kitab1, (2014). Yunus Emre Enstitüsü. Yunus Emre Enstitüsü Yedi İklim Türkçe B2 Ders Kitab1, (2014). Yunus Emre Enstitüsü. Yunus Emre Enstitüsü Yedi İklim Türkçe C1 Ders Kitab1, (2014). Yunus Emre Enstitüsü. Yunus Emre Enstitüsü Yedi İklim Türkçe C2 Ders Kitabı, (2014). Yunus Emre Enstitüsü. 